\title{
Modulation of ex-vivo uterine contraction by the methanol leaf extract of Alchornea laxiflora Benth. (Euphorbiaceae) and preliminary spectrometric identification of associated secondary metabolites
}

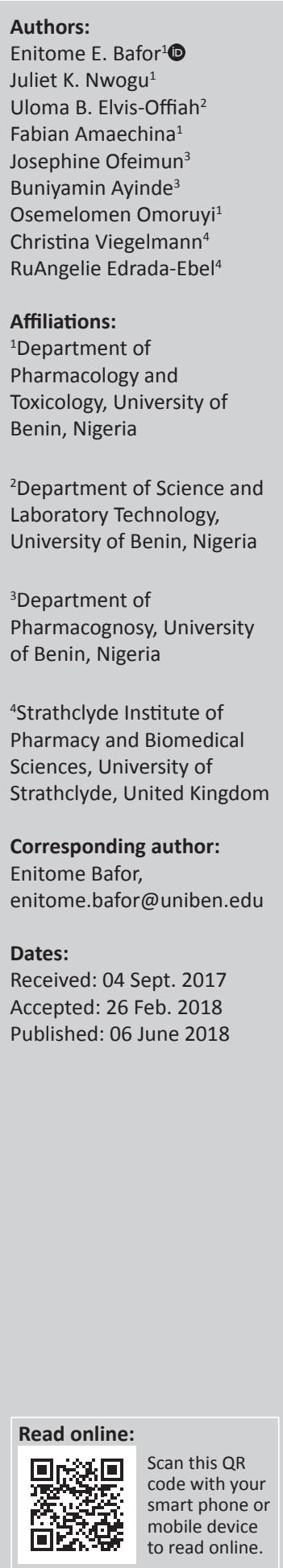

Authors:

Enitome E. Bafor ${ }^{1}$

Juliet K. Nwogu

Uloma B. Elvis-Offiah ${ }^{2}$

Fabian Amaechina ${ }^{1}$

Josephine Ofeimu

Osemelomen Omoruy

Christina Viegelmann ${ }^{4}$

RuAngelie Edrada-Ebe

Affiliations:

Toxicology, University of

Benin, Nigeria Laboratory Technology,

${ }^{3}$ Department of

Pharmacognosy, University

${ }^{4}$ Strathclyde Institute of

Pharmacy and Biomedical

Sciences, University of

Corresponding author:

Enitome Bafor,

Dates:

Accepted: 26 Feb. 2018

mobile device

to read online.
Background: The leaves of Alchornea laxiflora are traditionally used in the south of Nigeria to prevent preterm births.

Aim: This study was designed to investigate the activity of $A$. laxiflora on uterine contractility.

Setting: The leaves of the plant were collected from forests in Egor, Benin City, Nigeria.

Methods: The leaves were cleaned and extracted in methanol. The extract $(0.005 \mathrm{mg} / \mathrm{mL}-$ $3.5 \mathrm{mg} / \mathrm{mL}$ ) was tested on spontaneous uterine contraction and on oxytocin-induced contraction in normal and $\mathrm{Ca}^{2+}$-free media. The plant extract $(0.0035 \mathrm{mg} / \mathrm{mL}, 0.035 \mathrm{mg} / \mathrm{mL}$, $0.35 \mathrm{mg} / \mathrm{mL}$ and $3.5 \mathrm{mg} / \mathrm{mL}$ ) was tested on high $\mathrm{KCl}$-induced uterine contractions $(80 \mathrm{mM})$. The plant extract $(3.5 \mathrm{mg} / \mathrm{mL})$ was also studied in the presence of amiodarone and glibenclamide in separate experiments. Mass spectrometric analysis was additionally performed on the plant extract in order to identify significant secondary metabolites that may have contributed to the activity of the plant.

Results: The plant extract inhibited spontaneous, oxytocin and high $\mathrm{KCl}$-induced uterine contractions and also significantly inhibited $(p<0.01)$ oxytocin-induced uterine contraction in $\mathrm{Ca}^{2+}$-free medium. The plant extract significantly inhibited $(p<0.01$ and $p<0.05)$ oxytocin's amplitude in the presence of amiodarone and glibenclamide, respectively. Secondary metabolites belonging to classes of fatty acids, glycols, terpenes, flavonoid glycosides and porphyrins were identified.

Conclusion: Alchornea laxiflora inhibited mouse uterine contractility possibly through interaction with potassium and calcium channels. Of the known metabolites identified, 3-deoxy-arabino-hept-2-ulosonic acid, 17-hydroxyingenol and phaeophorbide-a methyl inhibit uterine contractility and may contribute to the activity of A. laxiflora in utero.

\section{Introduction}

Uterine contractions are involved in preterm labour (PTL) and dysmenorrhoea. Preterm labour, which leads to preterm births (PTBs), is a major cause of perinatal mortality and morbidity (Goldenberg 2002; Goldenberg et al. 2008). Premature infants are highly susceptible to potentially life-threatening complications, which include, but are not limited to, jaundice, hypoglycaemia, hypothermia, infection and respiratory distress syndrome (Steer \& Flint 1999). Although some improvements in neonatal survival rates because of improved neonatal care have been observed in recent years, the incidence of PTB itself has seen little improvements (Bocking 1998). Preterm birth originates from premature uterine contractions and is still one of the major obstetrical problems (Maltaris et al. 2006). Several drugs have been used as tocolytics and they include $\beta$-adrenoceptor mimetics, calcium antagonists, prostaglandin (PG) inhibitors and alcohol (Keirse 2003). Tocolysis (pharmacological inhibition of uterine contractility) aids in counteracting PTL and postponing delivery and is still the current mainstay of PTL management. Use of tocolytics is an important intervention as it enables delivery to be delayed long enough for transfer of the mother to a specialist tertiary centre or for corticosteroids to be administered to the mother which promotes maturation of foetal lung (Goldenberg 2002). However, the wide range of tocolytics in

How to cite this article: Bafor, E.E., Nwogu, J.K., Elvis-Offiah, U.B., Amaechina, F., Ofeimun, J., Ayinde, B. et al, 2018, 'Modulation of exvivo uterine contraction by the methanol leaf extract of Alchornea laxiflora Benth. (Euphorbiaceae) and preliminary spectrometric identification of associated secondary metabolites', Journal of Medicinal Plants For Economic Development 2(1), a33. https://doi. org/10.4102/jomped.v2i1.33

Copyright: @ 2018. The Authors. Licensee: AOSIS. This work is licensed under the Creative Commons Attribution License. 
use suggests that an ideal drug is yet unavailable (Keirse 2003). The most frequently-used tocolytic drugs today are the $\beta$-adrenoceptor mimetics, which are known to have a number of adverse effects (Berkman et al. 2003). This, therefore, calls for the exploration of indigenous medicinal plants that could potentially lead to the discovery of new potent drug compounds with little or no adverse effects. Dysmenorrhea, on the other hand, is considered the most common gynaecological condition among women within the reproductive age and can be defined as painful menstrual cramps originating from the uterus, which remains underdiagnosed and under-treated (Campbell \& McGrath 1997; Coco 1999; Proctor et al. 2010). The pain experienced by women with dysmenorrhea can be significantly incapacitating and has been described as similar to renal colic pain (Ayan et al. 2012). The prevalence of dysmenorrhea is high and its consequences are extensive. Dysmenorrhoea has been reported to have a negative impact on different aspects of the personal lives of those affected, and this includes school or work performance, family relationships, and social and recreational activities (Eryilmaz, Ozdemir \& Pasinlioglu 2010; Ortiz 2010; Wong \& Khoo 2010). This is probably because the intense cyclic pain restricts physical activity (Chen et al. 2006; Dawood 1995; Zuliani et al. 2009). It has been reported that women with dysmenorrhoea have high levels of PGs, which are hormones that can mediate uterine contractility, causing cramping abdominal pain (Marjoribanks et al. 2010). Prostaglandins are allegedly released from disintegrating cells during endometrial sloughing, which results in myometrial hypercontractility that then leads to ischaemia and hypoxia of the uterine muscle and, ultimately, pain (Dawood 1988). The most common treatment for primary dysmenorrhea (PD) (which is dysmenorrhoea with no known pathology) includes non-steroidal antiinflammatory drugs (NSAIDs) that combat menstrual pain by reducing intrauterine pressure and inhibiting the enzyme necessary for synthesis of prostaglandin $\mathrm{F} 2$ alpha $\left(\mathrm{PGF}_{2 \sigma}\right)$, leading to reduced levels in menstrual fluid. However, a reasonable percentage (about 15\%) of women who suffer from dysmenorrhea have been reported to respond poorly or are intolerant to PG inhibitors (Campbell \& McGrath 1997). The failure rate of NSAIDs falls between $20 \%$ and $25 \%$ (Dawood 1995), and is often contraindicated in some women (Taylor, Miaskowski \& Kohn 2002). Non-steroidal antiinflammatory drugs have long-term adverse effects which include disorders of the liver, kidney and digestive systems (Liu et al. 2011). Many women have therefore resorted to alternative therapies including non-pharmacologic therapies in order to manage their menstrual discomfort (Campbell \& McGrath 1997; Ogunfowokan \& Babatunde 2010; Ou et al. 2012). Oral contraceptives (OCPs) have also been used to manage dysmenorrhoea by suppressing ovulation and causing a thinned endometrial lining that results in reduced menstrual fluid volume, reduced amount of PG produced and consequently reduction of uterine contractions and therefore pain (Creatsas et al. 1990). However, OCPs can cause side effects, including nausea and water retention, and are contraindicated in women who intend to get pregnant (Hendrix \& Alex 2002). Surgical interruption of the pelvic nerve pathways has also been used in women, but the longterm efficacy of this method lacks evidence and it is not a commonly-accepted procedure (Proctor et al. 2010). The limitations associated with these conventional treatments have made herbal medicines feasible alternatives for the treatment of PD (Park et al. 2014). Many patients who failed to respond to conventional PD treatments have been treated with herbal medicines (Chen et al. 2006; Proctor \& Murphy 2001).

Medicinal plants have been a valuable source of therapeutic agents, and still many of today's drugs are plant-derived natural products or their derivatives (Kinghorn et al. 2011; Newman \& Cragg 2012). Traditional cultures worldwide depend on herbal remedies for different conditions in menstrual disorders, pregnancy, birth and post-partum care. This, therefore, makes scientific investigation and documentation of traditional knowledge of medicinal plants a crucial event, which assists chemists and pharmacologists with starting points for 'targeted' analysis, discovery of novel therapies and natural drugs for the treatment of pregnancy and uterine-related issues (Gruber \& O'Brien 2011). For drug discovery targeting dysfunctional labours, medicinal plants with oxytocic or uterine stimulating activities are of significant interest, while for PTLs, those with uterine relaxing activities are sought. Similarly, use of herbal medicines in dysmenorrhoea has received some attention (Mirabi et al. 2014; Van Andel et al. 2014), which signifies the importance in the search for new remedies from medicinal plants. The tropical plant, Alchornea laxiflora (AL) (Benth) Pax and Hoffman, of the Euphorbiaceae family, is one of such medicinal plants used by traditional healers in the south of Nigeria for managing uterine contractility, particularly in the prevention of miscarriages (personal communication with traditional healer Mr Eyohan). It is called Uwenriotan by Edo natives, Ububo in the Igbo language and Ijan or Opoto in the Yoruba language, Nigeria. It is a broad-leafed shrub that sheds its leaves annually and grows to a height of about $6 \mathrm{~m}-10 \mathrm{~m}$. It can be found abundantly in Nigeria, Cameroon, in DR Congo, throughout East Africa and in Zimbabwe (Burkill 1994). The stems, especially the branches, are used in Nigeria as chew-sticks and the leaves are used to preserve cola nut in Nigeria. Other traditional use includes the management of piles, dysentery, malaria, eczema, cough and high fever (Jayeoba, Ijeomah \& Ogara 2012). The decoctions of the leaves of AL have been reported to have antimicrobial effects (Oloyede et al. 2010), antioxidant activity (Farombi et al. 2003), hepatoprotective effects (Oloyede et al. 2011) and have been shown to exert a progesterone-like effect (Bafor et al. 2016). For PTL prevention, the leaves of AL are collected fresh, preferably at dawn and dusk, washed and squeezed into a glass full of water. The mixture is then filtered and mixed with 'calabash chalk' or 'calabash clay', often referred to as 'eko' in Nigeria, and the concoction is taken twice daily (morning and evening) after conception for a period of six months (personal communication with traditional healer Mr Eyohan). In the search for potential targets for new therapies in managing PTL and dysmenorrhoea, this study was aimed at investigating the activity of the plant AL on 
uterine contractility and to additionally investigate possible mechanisms of action. This study is also aimed at identifying significant secondary metabolites present in the plant that may have contributed to the plant's biological activities.

\section{Materials and method}

\section{Plant material}

Fresh leaves of AL were collected from Egor, $6.3350^{\circ} \mathrm{N}$ $5.6038^{\circ} \mathrm{E}$ Benin City in Edo state, Nigeria, in April 2015, with an average humidity of $75 \%$ and an average temperature of $35^{\circ} \mathrm{C}$. Identification was done by Dr H.A. Akinnibosun of the Department of Plant Biology and Biotechnology, University of Benin, Nigeria, and authenticated by Prof. B.A. Ayinde of the Department of Pharmacognosy, University of Benin, Nigeria. A voucher specimen number of UBHe0286 was provided.

\section{Animals}

Mature non-pregnant female albino mice weighing an average of $25 \mathrm{~g} \pm 0.57 \mathrm{~g}$, aged $4-5$ months, were obtained from the animal house, Department of Pharmacology and Toxicology, Faculty of Pharmacy, University of Benin, Edo state, Nigeria. The animals were housed in plastic cages at an environmentally controlled room temperature of approximately $27^{\circ} \mathrm{C} \pm 5^{\circ} \mathrm{C}$ and lighting conditions of approximately 11 or $13 \mathrm{~h}$ light and dark cycles. Relative humidity ranged from $80 \%$ to $85 \%$. The animals were handled as much as possible according to the standards of the Public Health Service Policy on Humane Care and Use of Laboratory Animals (National Research Council 2010; NIH 2015). The animals were maintained on a standard diet of animal pellets and clean tap water.

\section{Drugs and chemicals}

Methanol $(\mathrm{MeOH})$ of high analytical grade (Pharmatrends, Nigeria) and Tween 80 (Sigma Aldrich, Dorset, UK) were solvents used in this study. Salts for the physiological solution were obtained from BDH Chemicals, England. Other drugs used in the study include oxytocin (OT) (Laborate Pharmaceuticals, Haryana, India), amiodarone (AM) and glibenclamide (GLB) (Sigma Aldrich) and diethylstilboesterol (Sigma Aldrich). For the mass spectrometric experiments, $\mathrm{MeOH}$, dichloromethane (DCM), acetonitrile $(\mathrm{MeCN})$ and formic acid were purchased (Fisher Scientific, Hemel Hempstead, UK). All reagents were of analytical grade.

\section{Extraction of the plant material}

The collected leaves were cleaned and freed of debris before being shade-dried for two weeks. The dried leaves were then grounded using a milling machine (Christy Norris, England). The powdered samples were kept in airtight containers and stored in the refrigerator at $4^{\circ} \mathrm{C}$. The powdered material (855.24 g) was subsequently extracted in $\mathrm{MeOH}$ using a Soxhlet apparatus. Exhaustive extraction was performed for $48 \mathrm{~h}$ and the resulting solution was filtered and concentrated in a rotary evaporator set at $40^{\circ} \mathrm{C}$. The concentrate obtained was dried in an oven at $40^{\circ} \mathrm{C}$ and the extract weight was determined to be $122.3 \mathrm{~g}$ (percentage yield was $14.3 \% \mathrm{w} / \mathrm{w}$ ). The extract was then stored in airtight containers and kept in the refrigerator $\left(\sim 4^{\circ} \mathrm{C}\right)$ till needed.

\section{Contractility studies}

\section{Uterine tissue preparation}

Each mouse (four animals per protocol) was administered $1.0 \mathrm{mg} / \mathrm{kg}$ diethylstilboesterol (DES) orally constituted in Tween 80 and distilled water (1:1), $24 \mathrm{~h}$ prior to the day of experiments. Oral administration was done using a feeding syringe. Dose and route of DES administration had been previously determined in our laboratory to effectively induce oestrus. On the day of the experiment, vaginal smears were obtained and prepared as previously described (Caligioni 2009; Cora, Kooistra \& Travlos 2015). Briefly, with the aid of a Pasteur pipette $(0.1 \mathrm{~mm})$, the vaginal smears were collected, fixed with ethanol and stained with a drop of Gentian violet. The smears were then observed under a microscope using a $\times 10$ objective lens in order to ascertain the oestrus stage animals in pro-oestrus and oestrus stages were selected and humanely killed by cervical dislocation and the uterine horns were immediately excised and placed into a Petri dish containing previously warmed and aerated physiological salt solution. The uterine tissues were cleaned of connective tissues and one horn was dissected into half to obtain a segment of the uterine horn. Tissue lengths of approximately $1 \mathrm{~mm}-2 \mathrm{~mm}$ each were obtained. The uterine segment was then mounted in a warmed $10 \mathrm{~mL}$ organ bath maintained at $37^{\circ} \mathrm{C}$ and containing aerated physiological solution. The physiological salt solution used was of the following composition in $\mathrm{M}$ : $\mathrm{NaCl} 154.00, \mathrm{NaHCO}_{3}$ 5.95, D-glucose 2.78, $\mathrm{KCl} 5.63$ and $\mathrm{CaCl}_{2} \cdot 2 \mathrm{H}_{2} \mathrm{O} 2.05$ (Bafor, Obarisiagbon \& Itamaomon 2015).

\section{Experimental protocol}

The uterine tissues were mounted in organ baths and equilibrated under resting tensions of $4.90 \mathrm{mN}$ for $30-45 \mathrm{~min}$ or until regular contractions were obtained (time duration used was dependent on when regular contractions were obtained) (Sukwan, Wray \& Kupittayanant 2014). The force and frequency of uterine contractions in the longitudinal muscle layers were measured using a 7003E-isometric force transducer (Ugo Basile, Varise, Italy) connected to a 17400 data capsule digital recorder with an inbuilt bridge amplifier (Ugo Basile).

\section{Experiment on the effect of extract on spontaneous uterine contraction}

The cumulative effect of the extract on uterine smooth muscle contractility was investigated (Bafor et al. 2013). Concentration-response relationships were obtained at $0.005 \mathrm{mg} / \mathrm{mL}-3.5 \mathrm{mg} / \mathrm{mL}$. The concentration used had been predetermined in our laboratory as concentrations covering the range of effects of the extract. A contact time of $3 \mathrm{~min}$ was allowed following each concentration of 
extract administered. After each set of administration, the tissues were washed three times and a washout period minimum of $10 \mathrm{~min}$ was allowed for the tissue to recover before the next administration (Bafor et al. 2017).

\section{Experiment on the effect of extract on oxytocin-induced uterine contraction}

The effect of the extract on OT-induced uterine contraction was investigated. This was done by first performing a concentration response to OT $(0.00017 \mathrm{ng} / \mathrm{mL}-4.98 \mathrm{ng} / \mathrm{mL})$ in the absence of the extract, which was then repeated in the presence of cumulative sub-maximum concentrations of the extract at $0.35 \mathrm{mg} / \mathrm{mL}$ and $3.5 \mathrm{mg} / \mathrm{mL}$ at $5 \mathrm{~min}$ each. Conversion of OT from international units (IUs) to milligram was in accordance with the World Health Organization recommendation, where $10 \mathrm{IU}=16.6 \mu \mathrm{g} / \mathrm{mL}$ (World Health Organization 2016).

\section{Experiment on high potassium chloride-induced uterine contractility}

The activity of the extract on high $\mathrm{KCl}$-induced $(80 \mathrm{mM})$ tonic uterine contracture was investigated. $\mathrm{KCl}(80 \mathrm{mM})$ was added to the bath containing the uterine tissues and left in contact with the tissue for $5 \mathrm{~min}$, and without washing, cumulative concentrations of the extract $(0.0035 \mathrm{mg} / \mathrm{mL}-$ $3.5 \mathrm{mg} / \mathrm{mL}$ ) were determined.

\section{Experiment on the effect of the extract in $\mathrm{Ca}^{2+}$-free medium}

After tissue equilibration for $30 \mathrm{~min}$, the physiological salt solution was changed to one without calcium and containing $0.1 \mathrm{mM}$ of ethylenediaminetetraacetic acid (EDTA). The tissue was then equilibrated in the $\mathrm{Ca}^{2+}$-free solution for a further $15 \mathrm{~min}$. After equilibration, OT $(0.05 \mathrm{mM})$ was added and a contact time of $5 \mathrm{~min}$ was allowed. Without flushing, the extract $(3.5 \mathrm{mg} / \mathrm{mL})$ was added. A contact time of $5 \mathrm{~min}$ was allowed for the extract concentration.

\section{Experiment on interaction of extract with $\mathrm{K}^{+}$-channels}

The effect of the extract $(3.5 \mathrm{mg} / \mathrm{mL})$ on OT-induced contraction $(0.05 \mathrm{mM})$ was determined in the absence and presence of AM (0.04 mM) and GLB (0.04 mM) - both adenosine triphosphate (ATP)-sensitive $\mathrm{K}^{+}$-channel blocker. This was achieved by addition of OT to the tissue bath and this was left in contact for $5 \mathrm{~min}$ and without flushing, the extract was added and left for a further $5 \mathrm{~min}$. Without washing, AM or GLB was then added to the bath and the effect was observed for a further $5 \mathrm{~min}$.

\section{Liquid chromatography-high-resolution Fourier transform mass spectrometry identification of constituents in extract}

Samples were prepared at a concentration of $1 \mathrm{mg} / \mathrm{mL}$ in 80:20 MeOH:DCM. A solvent blank was also included. Liquid chromatography-high-resolution Fourier Transform mass spectrometry (LC-HRFTMS) analysis was performed on a Dionex UltiMate-3000 (DIONEX, Sunnyvale, CA, USA) coupled to a Thermo Scientific Exactive Orbitrap system (Thermo Fisher Scientific (Bremen) GmbH, Bremen, Germany).
The mass accuracy was set to less than $3.0 \mathrm{ppm}$. The instrument was externally calibrated according to the manufacturer's instructions before the run. An ACE C18 column with dimensions of $75 \times 3.0 \mathrm{~mm}$ from Hichrom Ltd., Reading, UK, was used. Parameters used were as previously described (Bafor et al. 2016). Briefly, $10 \mu \mathrm{L}$ of the sample was injected from the vial and elution flow rate was set at $300 \mu \mathrm{L} / \mathrm{min}$ with water (A) and $\mathrm{MeCN}(\mathrm{B})$, both of which contained $0.1 \%$ formic acid. A gradient flow was used, starting with $10 \% \mathrm{~B}$ and increasing to $100 \% \mathrm{~B}$ in $30 \mathrm{~min}$. The mobile phase was maintained for 5 min at $100 \%$ B; this was followed by equilibration of the column with $10 \% \mathrm{~B}$. The resulting data files were divided into positive and negative data sets using ProteoWizard (Kessner et al. 2008) prior to data mining that was performed with the use of MZmine 2.10 (Pluskal et al. 2010). Peak detection was accomplished using the centroid mass detector and a noise level of 1000 was set. The chromatogram builder generated peak lists from the mass lists obtained from the previous step. The minimum time span was $0.2 \mathrm{~min}$, the minimum height was 10000 intensity and the $m / z$ tolerance was set at 0.0001 $m / z$ or 5 ppm. Chromatogram deconvolution was accomplished using the local minimum search algorithm with the following parameters: threshold $(90 \%)$, search minimum in retention time (RT) range (0.4 min), minimum relative height $(5 \%)$, minimum absolute height (10 000 intensity), minimum ratio of peak top or edge (Goldenberg 2002) and peak duration range (0.2-5.0 $\mathrm{min})$. The peak lists were de-isotoped using the isotopic peaks grouper with an $m / z$ tolerance of $0.001 \mathrm{~m} / z$ or $5 \mathrm{ppm}, \mathrm{RT}$ tolerance of $0.1 \mathrm{~min}$ (absolute) and maximum charge of 2 . The representative isotope was the most intense. The peak lists were then merged using the alignment function. The weight for $m / z$ and for RT was 20, and the RT tolerance was 5\%. The aligned peak lists were gap-filled using the PeakFinder, with an intensity tolerance of $1 \%$ and RT tolerance of $0.5 \mathrm{~min}$ (absolute) (Macintyre et al. 2014). The adducts were identified together with other complexes that may have formed within the metabolite pool. The chemical formulae of each peak were predicted using the formula prediction tool developed by MZmine. ChemBioFinder version 13 (PerkinElmer Informatics, Cambridge, UK) was used to access hits from the database.

\section{Data analysis}

The mean frequency and amplitude were computed from contractions occurring at the last $3 \mathrm{~min}$ of the phasic contractions using the GraphPad Prism (version 7.03; GraphPad Software Inc, San Diego, CA, USA). Results were obtained as percentages of control applications (control = $100 \%$ ) where necessary and changes in force (amplitude) or frequency were expressed with respect to control (100\%). All data shown were expressed as mean \pm standard error of mean (SEM) and $n$ represents the number of animals (in this study, $n=4$ animals). Significance was evaluated using appropriate $t$-tests, and where necessary, one-way analysis of variance with Dunnett's post hoc test and $p$ values $\leq 0.05$ was taken to represent the minimum significance in all cases.

In data sets with sufficient data points, mean log concentrationresponse curves were analysed by fitting data to a variable slope 
logistic equation, using the following equation values: $Y=$ Bottom $+($ Top-Bottom $) /\left(1+10^{\wedge}\left(\left(\operatorname{LogIC}{ }_{50}-X\right) *\right.\right.$ HillSlope $\left.)\right)$, where $Y$ is the response that starts at the bottom and goes to the top in sigmoid shape, $X$ is the logarithm of concentration and half maximal inhibitory concentration $\left(\mathrm{IC}_{50}\right)$ is the concentration that gives a response half way between bottom and top.

\section{Ethical considerations}

Ethical permission was obtained prior to start of the experiments from the Faculty of Pharmacy Animal Ethics Committee, University of Benin, Nigeria, and the study was provided an approval reference number: EC/FP/016/08.

\section{Results}

\section{Vaginal cytology of the experimental animals}

Representative exfoliative vaginal cytology for the stage of the oestrus cycle of animals utilised for this study is presented in Figure 1. The relative prevalence of the cell type was used to ascertain the oestrus phase for each recipient mouse. Typically, animals in the oestrus and pro-oestrus phases were utilised for this study.

\section{Effect of extract on spontaneous uterine contraction}

Cumulative concentration-response experiments were performed to determine the effects of the extracts on the force and frequency of spontaneous uterine contractions. Response curves were determined for AL $(n=5)$. Alchornea laxiflora was observed to inhibit spontaneous uterine contractions at higher concentrations (Figure 2). However, lower concentrations appeared to slightly increase contractility (Figure 2a). Both the amplitude and frequency of spontaneous uterine contractions were inhibited by AL; however, AL appeared to have more effect on the amplitude than on the frequency (Figure $2 b$ ).

\section{Effect of extract on oxytocin-induced uterine contractions}

Experiments were performed to characterise the activities of AL on OT-induced uterine contractions. Alchornea laxiflora was observed to inhibit OT-induced uterine contractility. Two concentrations of AL were used for this phase of
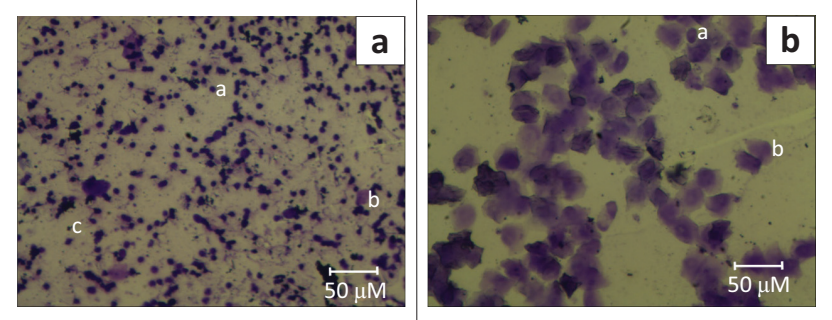

FIGURE 1: Representative $\times 100$ images of gentian violet-stained exfoliative vaginal cytology from animals used in this study corresponding to: (a) prooestrus phase with mainly nucleated cornified epithelial cells undergoing cornification (a), few cornified epithelial cells (b), and few lymphocytes (c). (b) Oestrus phase with mainly anucleated cornified epithelial cells (b), sparselynucleated epithelial cells (b)? the study. At the lower concentration of $0.35 \mathrm{mg} / \mathrm{mL}$, no marked inhibition was observed for both amplitude and frequency of contraction, but a reduction of the baseline tension was seen (Figure 3a). However, at $3.5 \mathrm{mg} / \mathrm{mL} \mathrm{AL}$, there was a rightward shift in the amplitude and frequency concentration-response curves of OT (Figure $3 \mathrm{~b}$ and c).

\section{Effect of extract on high potassium chloride- induced uterine contraction}

Characterisation of the actions of $\mathrm{AL}$ to high $\mathrm{K}^{+}$solution was performed. The possibility of interaction of AL with extracellular calcium channels involved in high $\mathrm{K}^{+}$depolarisation of smooth muscles (Triggle 1987) was investigated. High $\mathrm{KCl}$ solution produced a rapid increase in force that was immediately preceded by a decline and rapidly oscillating production of force (Crichton et al. 1993). Alchornea laxiflora inhibited high $\mathrm{KCl}$-induced contraction and this inhibition was more pronounced at the concentration of $3.5 \mathrm{mg} / \mathrm{mL}$ (Figure 4a). This was observed as a decrease in the amplitude of response elicited by high $\mathrm{KCl}$ (Figure $4 \mathrm{~b}$ ).

\section{Effect of extract in $\mathrm{Ca}^{2+}$-free medium}

Further experiments were designed to investigate whether AL extract could inhibit internal $\mathrm{Ca}$ mobilisation from the sarcoplasmic reticulum (Arrowsmith \& Wray 2014; Wray \& Arrowsmith 2012). To do so, internal Ca mobilisation was

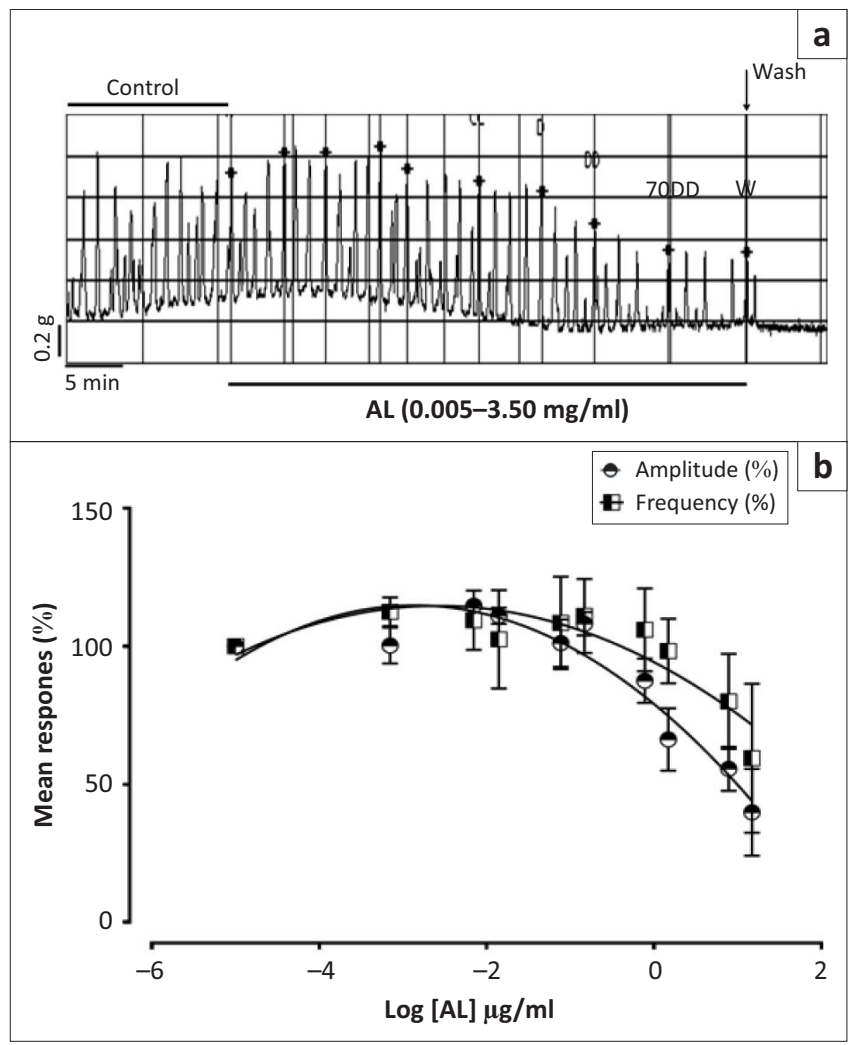

FIGURE 2: Effect of Alchornea laxiflora ( $\mathrm{AL}$ ) on spontaneous uterine contractions. Figure a represents original recordings of the activity of $A L$ on spontaneous uterine contractions. Figure $b$ represents concentration-response curves for the amplitude and frequency of spontaneous contractions in the presence of AL. Alchornea laxiflora displayed a somewhat biphasic effect on spontaneous contractions, with the lower concentrations showing mild stimulation and higher concentrations showing marked depression of amplitude and frequency. $n=4$ animals. 


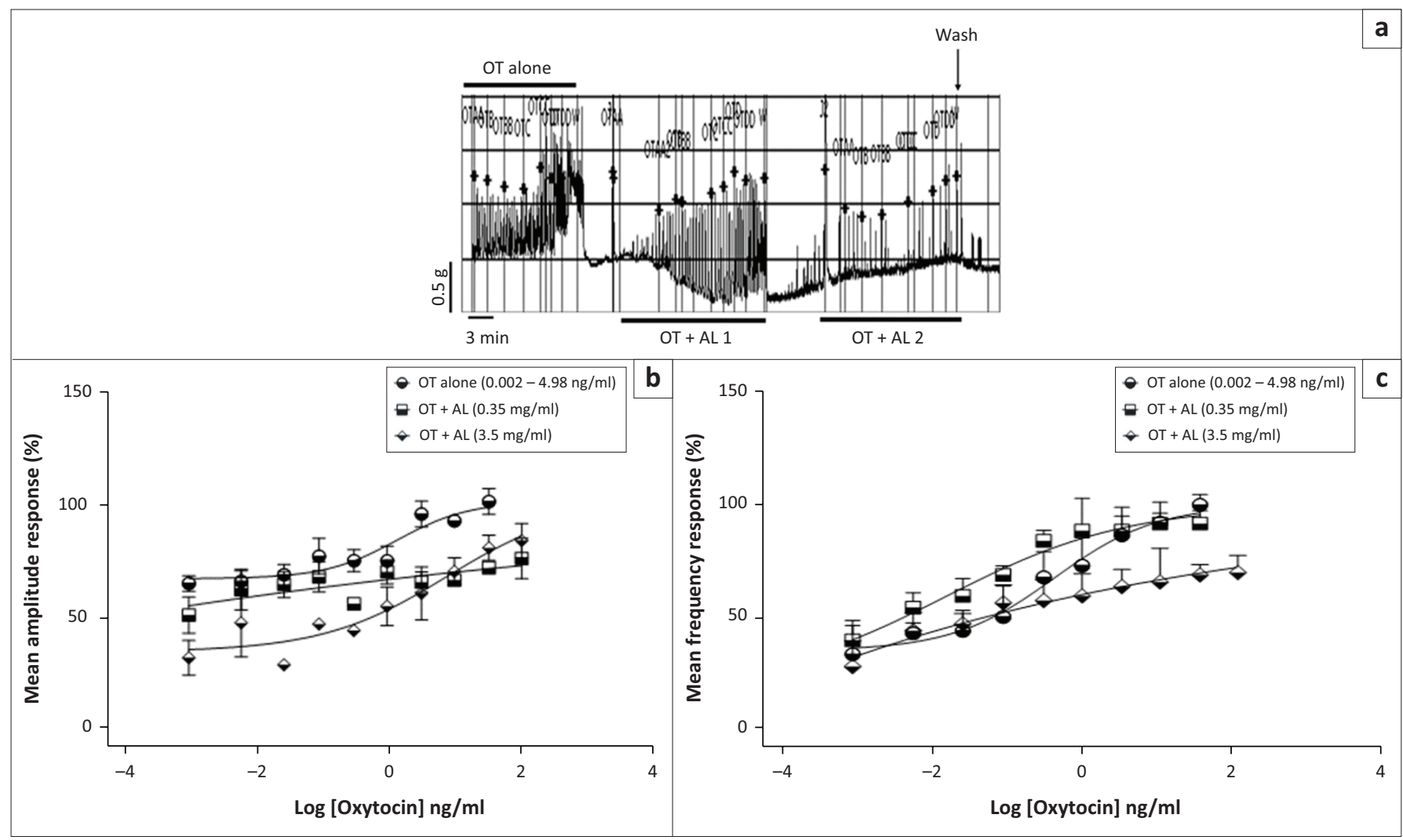

FIGURE 3: Effect of oxytocin (OT)-induced uterine contraction in the absence and presence of Alchornea laxiflora (AL). Panel a shows original representative recording of the effect of AL on OT-induced uterine contraction. Alchornea laxiflora 1 and AL2 $(0.35 \mathrm{mg} / \mathrm{mL}$ and $3.5 \mathrm{mg} / \mathrm{mL}$, respectively). Panel b represents concentration-response curves for the amplitude of OT in the absence and presence of OT, while panel c represents concentration-response curves for the frequency of OT in the absence and presence of OT. $n=4$ animals.

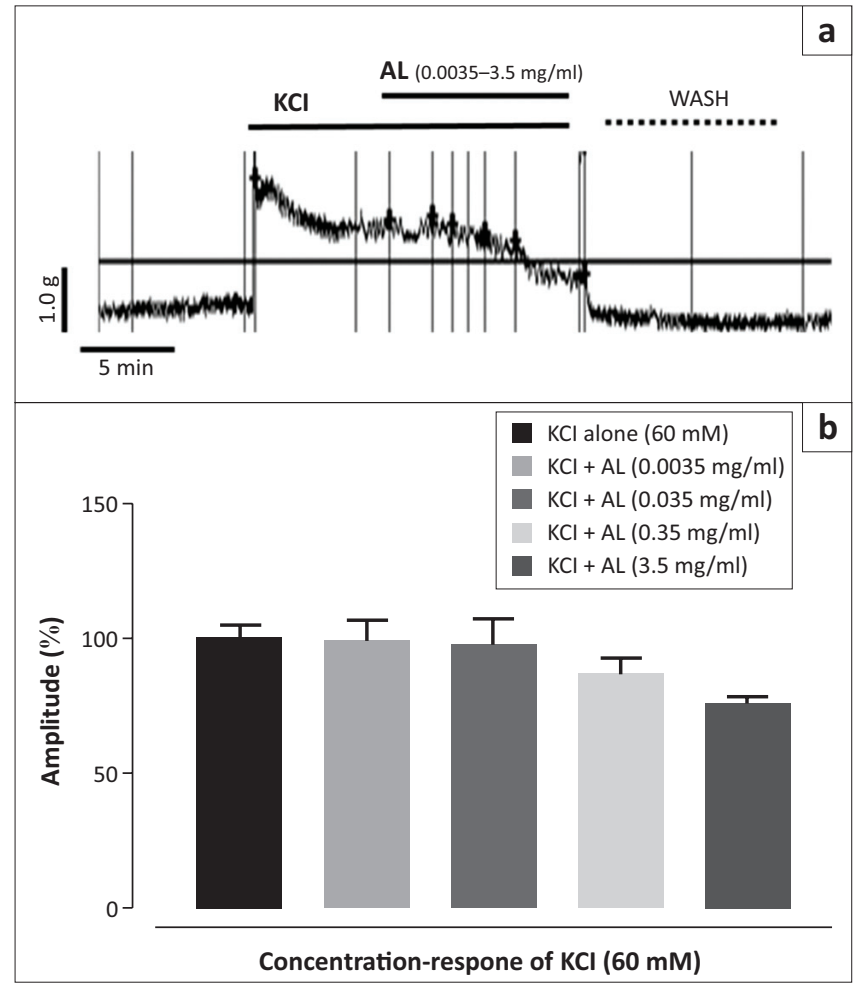

FIGURE 4: Effect of Alchornea laxiflora (AL) on high $\mathrm{KCl}$-induced ( $60 \mathrm{mM}$ ) uterine contraction. Figure a depicts original recording representative of the effect of $\mathrm{AL}$ on high $\mathrm{KCl}$-induced contraction. Figure $\mathrm{b}$ represents bar graph analysis of the effect of $\mathrm{AL}$ on high $\mathrm{KCl}$-induced uterine contraction. Alchornea laxiflora $(0.0035 \mathrm{mg} / \mathrm{mL}-3.5 \mathrm{mg} / \mathrm{mL})$ was observed to inhibit high $\mathrm{KCl}$-induced uterine contraction in this study (a). The inhibition observed was more pronounced at higher concentrations of $0.35 \mathrm{mg} / \mathrm{mL}$ and $3.5 \mathrm{mg} / \mathrm{mL}$, though considered not statistically significant. $n=4$ animals. blocked by utilisation of a Ca-free medium. In a medium containing zero-calcium, AL $(3.5 \mathrm{mg} / \mathrm{mL})$ reduced the contractions of OT-induced uterine contractions (Figure 5a). On analysis, a significant inhibition $(p<0.01)$ by AL on OTinduced contraction $(0.005 \mathrm{mM})$ was observed (Figure 5). Alchornea laxiflora reduced the amplitude of OT-induced contractions under these conditions to about $69.9 \%$ (Figure $5 b$ ).

\section{Effect of extract on oxytocin-induced uterine contractions in the presence of amiodarone, a $\mathrm{K}^{+}{ }_{\text {ATP }}$-dependent channel blocker}

A further inhibition of OT-induced $(0.05 \mathrm{mM})$ uterine contraction by $\mathrm{AL}(3.5 \mathrm{mg} / \mathrm{mL})$ was observed in the presence of AM (0.04 mM) (Figure 6a). This was shown in the bar plots where analysis showed that AL significantly inhibited $(p<$ 0.01) OT in the presence of AM (Figure 6b). Oxytocin was reduced by $\mathrm{AL}$ to $78.70 \%$ of the original amplitude of contraction, which was further reduced to $59.81 \%$ in the presence of AM (Figure 6b).

\section{Effect of extract on oxytocin-induced uterine contractions in the presence of glibenclamide, an adenosine triphosphate-dependent $\mathrm{K}^{+}$- channel blocker}

This experiment was performed in order to evaluate the specific interactions of AL with $\mathrm{K}^{+}$channels, ATP- sensitive potassium channels $\left(\mathrm{K}^{+}{ }_{\mathrm{ATP}}\right)$-, and $\beta$-adrenoceptors. Therefore, in the presence of AM (a $\mathrm{K}^{+}$-channel and $\beta$-adrenoceptor 

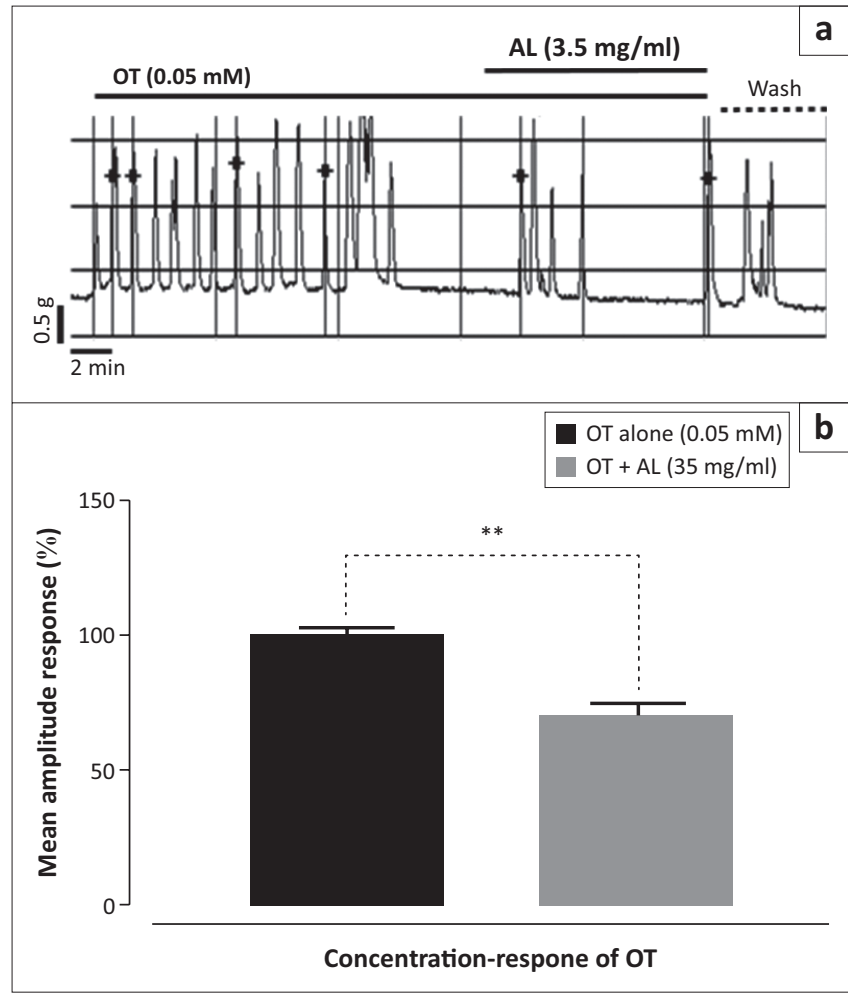

FIGURE 5: Effect of Alchornea laxiflora (AL) on oxytocin (OT)-induced uterine contraction in $\mathrm{Ca}^{2+}$-free medium. Figure a shows representative recordings of the effect of AL on OT-induced uterine contraction in media containing zero calcium. Figure $b$ shows bar plots analysing the effect of AL on OT-induced uterine contraction in $\mathrm{Ca}^{2+}$-free medium. A significant inhibition of OT by AL was observed under these conditions. $n=4$ animals; $* * p<0.01$

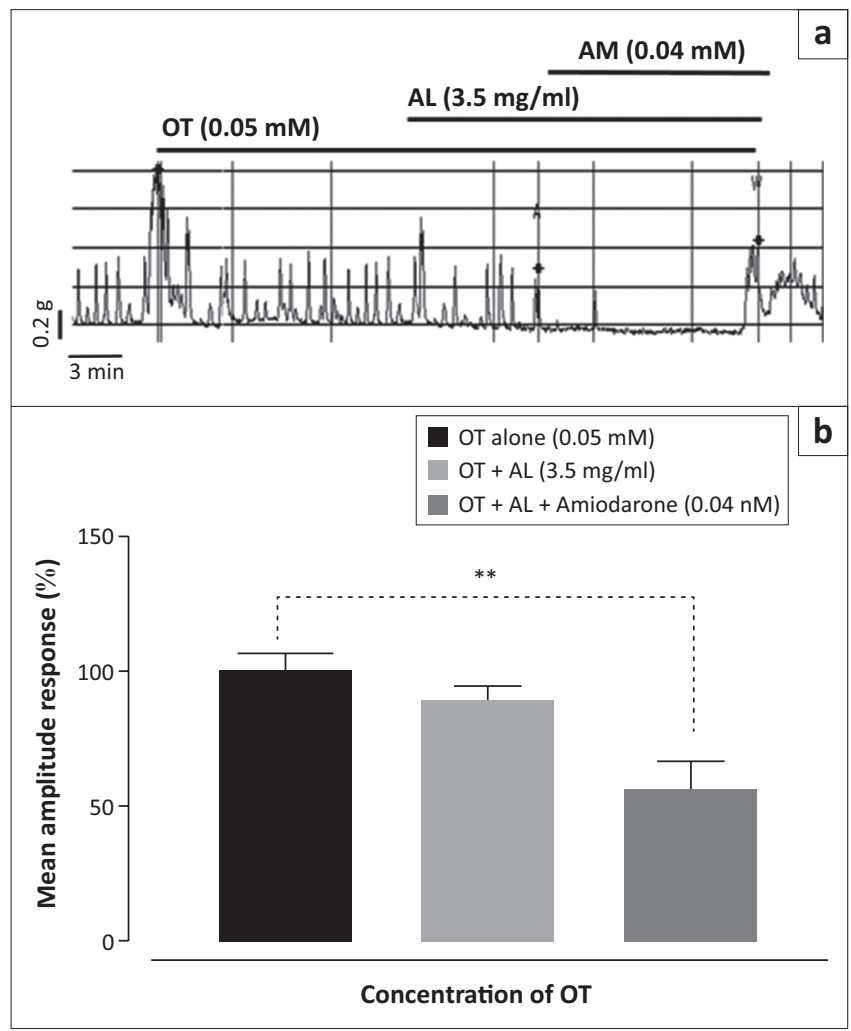

FIGURE 6: Effect of Alchornea laxiflora (AL) in the presence of amiodarone, a $\mathrm{K}^{+}$-channel blocker. Figure a represents original recording of the effect of $\mathrm{AL}$ on oxytocin (OT)-induced $(0.05 \mathrm{mM})$ uterine contraction in the absence and presence of amiodarone $(0.04 \mathrm{mM})$. Figure $b$ represents bar plot analysis of the response of OT to $A L$ in the absence and presence of amiodarone. Significant inhibition $(p<0.01)$ of OT by AL in the presence of amiodarone was observed. $n=4$ animals; $* * p<0.01 ; \mathrm{AM}=$ amiodarone. blocker) (Zhang et al. 2016) and in the presence of GLB $\left(\mathrm{K}^{+}{ }_{\text {ATP }}\right.$ inhibitor) (Luzi \& Pozza 1997), the inhibitory effect of AL on OT was evaluated. In the presence of AM, AL was observed to significantly inhibit $(p<0.05)$ OT-induced contraction (Figure 7). Similarly, in the presence of GLB, AL significantly inhibited $(p<0.05)$ OT-induced contraction (Figure 7). In both instances, the original inhibition by AL on OT was further potentiated.

\section{Mass spectrometric identification of secondary metabolites in the extract}

Significant secondary metabolites that make up the major constituents of AL were identified. The LC-HRFTMS results and database search (using Dictionary of Natural Products) enabled the detection of 18 significant compounds (Tables 1 and 2). Seven compounds were known (Table 1) and 11 were unknown (Table 2). The identified compounds are (1) 4-Amino-4-deoxyarabinose; $\alpha$-D-Pyranose-form, Me glycoside, (2) 2-Methyl-1,2,3,4butanetetrol; (2S,3R)-form, 4-Phosphate, (3) 2-Amino-4,5dihydroxy-3,4-dimethylpentanoic acid; (2S,3S,4R)-form, $\hat{\mathrm{I}}^{3}$ Lactone, (4) 3-Deoxy-arabino-hept-2-ulosonic acid, (5) Adipedatol, (6) 17-Hydroxyingenol; 17-Benzoyl, 3-angeloyl, 5-Ac and (7) Phaeophorbide-a; 10-Epimer, 3"-Me ester. The chromatogram depicted the individual peaks of the identified compounds (Figure 8) and the structures of the known identified compounds are also presented (Figure 9).

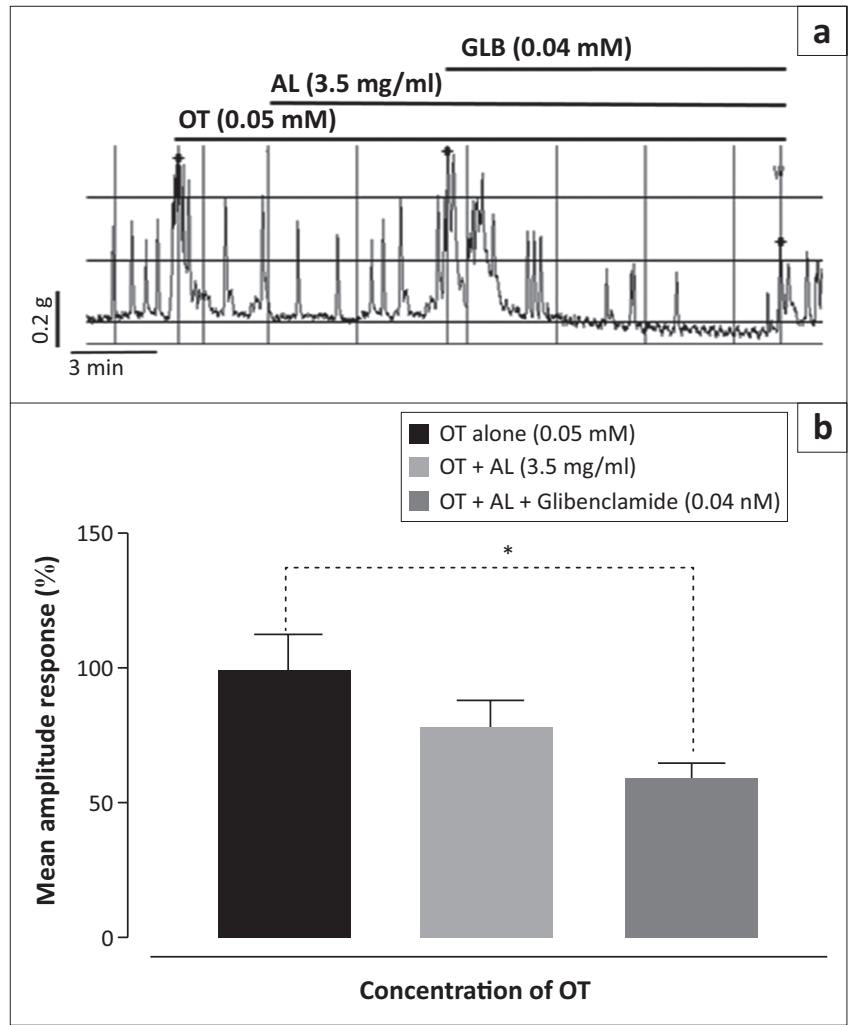

FIGURE 7: Effect of Alchornea laxiflora (AL) on oxytocin (OT)-induced uterine contraction in the presence of glibenclamide, an ATP-dependent $\mathrm{K}^{+}$-channel blocker. Figure a represents original recording of the effect of AL on OT-induced $(0.05 \mathrm{mM})$ uterine contraction in the absence and presence of glibenclamide $(0.04 \mathrm{mM})$. Figure $b$ represents bar plot analysis of the response of OT to AL in the absence and presence of glibenclamide. Significant inhibition $(p<0.05)$ of OT by AL in the presence of amiodarone was observed. $n=4$ animals; $* * p<0.05$; $\mathrm{GLB}=$ glibenclamide . 
TABLE 1: Putatively identified compounds in Alchornea laxiflora.

\begin{tabular}{|c|c|c|c|c|c|}
\hline & Compound name & Molecular formula & Molecular weight $(\mathrm{g} / \mathrm{mol})$ & $\mathrm{m} / \mathbf{z}$ & Rt (min) \\
\hline 1. & 4-Amino-4-deoxyarabinose; $\alpha$-D-Pyranose-form, Me glycoside & $\mathrm{C}_{6} \mathrm{H}_{13} \mathrm{NO}_{4}$ & 163.0843 & {$[M+1]^{+} 164.0915$} & 1.12 \\
\hline 2. & 2-Methyl-1,2,3,4-butanetetrol; (2S,3R)-form, 4-Phosphate & $\mathrm{C}_{5} \mathrm{H}_{13} \mathrm{O}_{7} \mathrm{P}$ & 216.0401 & {$[\mathrm{M}-1]^{-215.0328}$} & 1.14 \\
\hline 3. & $\begin{array}{l}\text { 2-Amino-4,5-dihydroxy-3,4-dimethylpentanoic acid; } \\
(2 S, 3 S, 4 R) \text {-form, } \text { İ}^{3} \text {-Lactone }\end{array}$ & $\mathrm{C}_{7} \mathrm{H}_{13} \mathrm{NO}_{3}$ & 159.0896 & {$[M+1]^{+} 160.0968$} & 1.17 \\
\hline 4. & 3-Deoxy-arabino-hept-2-ulosonic acid & $\mathrm{C}_{7} \mathrm{H}_{12} \mathrm{O}_{7}$ & 208.0582 & {$[\mathrm{M}-1]^{-2} 207.0509$} & 1.19 \\
\hline 5. & Adipedatol & $\mathrm{C}_{29} \mathrm{H}_{48} \mathrm{O}_{2}$ & 428.3651 & {$[M+1]^{+} 429.3724$} & 24.46 \\
\hline 6. & 17-Hydroxyingenol; 17-Benzoyl, 3-angeloyl, 5-Ac & $\mathrm{C}_{34} \mathrm{H}_{40} \mathrm{O}_{9}$ & 592.2690 & {$[M+1]^{+} 593.2763$} & 29.33 \\
\hline
\end{tabular}

TABLE 2: Unidentified compounds in Alchornea laxiflora.

\begin{tabular}{|c|c|c|c|c|c|}
\hline$S / N$ & Predicted molecular formula & Double bond equivalence & Molecular weight $(\mathrm{g} / \mathrm{mol})$ & $m / z$ & Rt (min) \\
\hline 8. & $\mathrm{C}_{6} \mathrm{H}_{8} \mathrm{~N}_{7} \mathrm{O}_{3}$ & 6.5 & 226.0688 & {$[M-1]^{-225.0616}$} & 1.12 \\
\hline 9. & $\mathrm{C}_{5} \mathrm{H}_{11} \mathrm{~N}_{4} \mathrm{O}_{3}$ & 2.5 & 175.0839 & {$[\mathrm{M}+1]^{+} 176.0912$} & 1.15 \\
\hline 10. & $\mathrm{C}_{16} \mathrm{H}_{16} \mathrm{~N}_{3} \mathrm{O}_{8}$ & 10.5 & 378.0930 & {$[\mathrm{M}-1]^{-} 377.0857$} & 1.16 \\
\hline 11. & $\mathrm{C}_{14} \mathrm{H}_{20} \mathrm{~N}_{4} \mathrm{O}_{9}$ & 7.0 & 388.1219 & {$[\mathrm{M}-1]^{-387.1146}$} & 1.16 \\
\hline 12. & $\mathrm{C}_{13} \mathrm{H}_{21} \mathrm{~N}_{5} \mathrm{O}_{7}$ & 6.0 & 359.1426 & {$[M+1]^{+} 360.1499$} & 1.16 \\
\hline 13. & $\mathrm{C}_{13} \mathrm{H}_{19} \mathrm{~N}_{5} \mathrm{O}_{10}$ & 7.0 & 405.1119 & {$[\mathrm{M}-1]^{-} 404.1046$} & 1.18 \\
\hline 14. & $\mathrm{C}_{7} \mathrm{H}_{13} \mathrm{NO}_{4}$ & 2.0 & 175.0838 & {$[M+1]^{+} 176.0911$} & 1.19 \\
\hline 15. & $\mathrm{C}_{28} \mathrm{H}_{29} \mathrm{~N}_{2} \mathrm{O}_{6}$ & 15.5 & 489.2028 & {$[\mathrm{M}-1]^{-} 488.1956$} & 7.46 \\
\hline 16. & $\mathrm{C}_{16} \mathrm{H}_{30} \mathrm{~N}_{3} \mathrm{O}_{4}$ & 3.5 & 328.2244 & {$[\mathrm{M}-1]^{-327.2172}$} & 11.09 \\
\hline 17. & $\mathrm{C}_{21} \mathrm{H}_{36} \mathrm{~N}_{2} \mathrm{O}_{6}$ & 5.0 & 412.2589 & {$[\mathrm{M}+1]^{+} 413.2662$} & 32.71 \\
\hline 18. & $\mathrm{C}_{43} \mathrm{H}_{58} \mathrm{NO}_{3}$ & 15.5 & 684.4288 & {$[M+1]^{+} 685.4360$} & 35.78 \\
\hline
\end{tabular}

Note: Double-bond equivalence (DBE) indicates number of rings and double bonds in the structure where 1 ring $=1 \mathrm{DBE} ; \mathrm{m} / \mathrm{z}=$ mass to charge ratio.

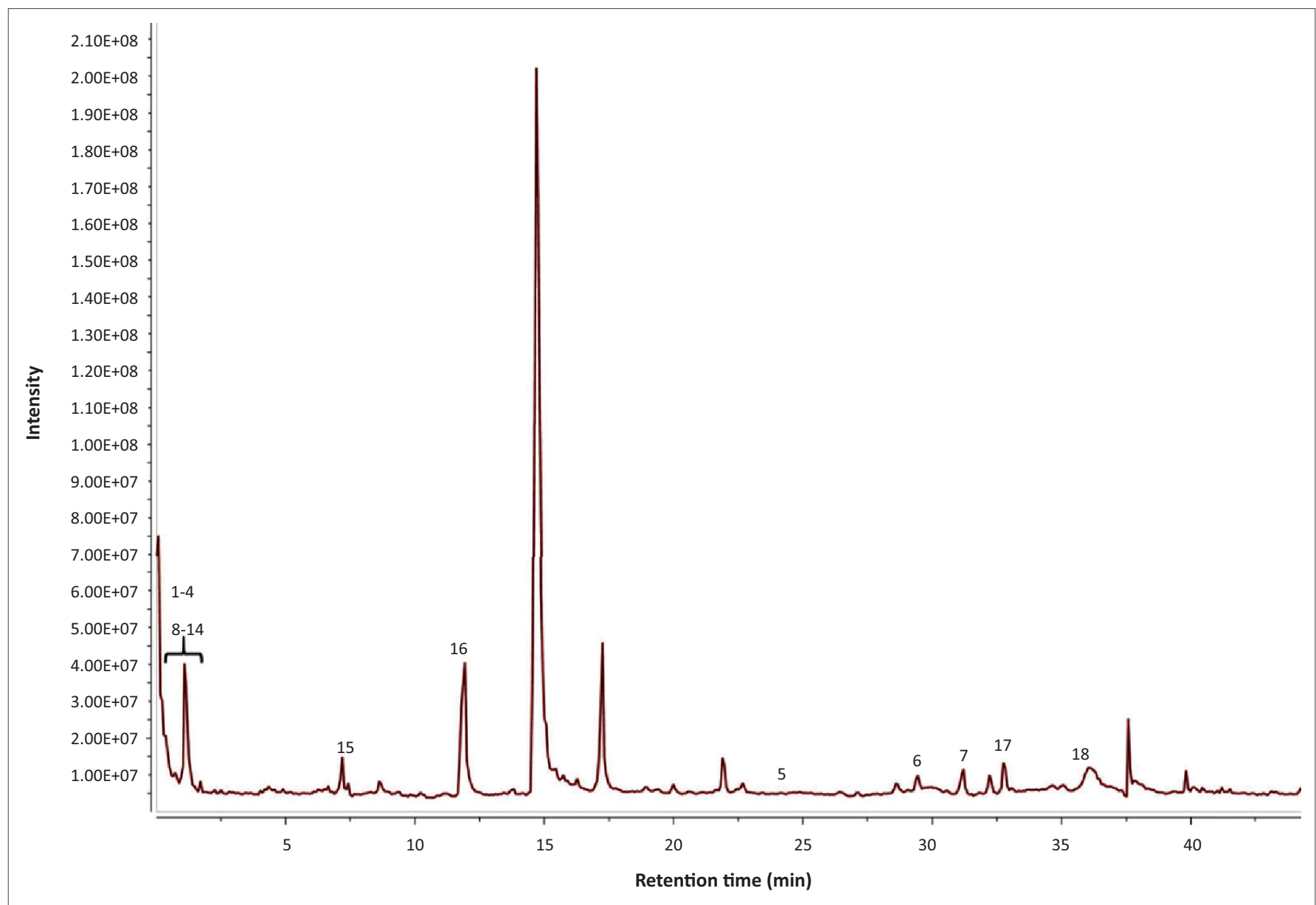

FIGURE 8: Total ion chromatogram for Alchornea laxiflora showing identified metabolites (1-7) and unidentified but detected metabolites (8-18). The identification, molecular formula, molecular weight, mass-to-charge ratio $(\mathrm{m} / \mathrm{z})$ and retention time (RT) in minutes are indicated in Tables 1 and 2. 
<smiles>N[C@@H](CO)C(O)[C@H](O)C=O</smiles>

[1]

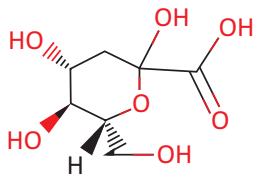

[4]<smiles>CC(O)(CO)C(O)CO</smiles>

[2]<smiles>CC(=C(N)C(=O)O)C(C)(C)O</smiles>

[3]

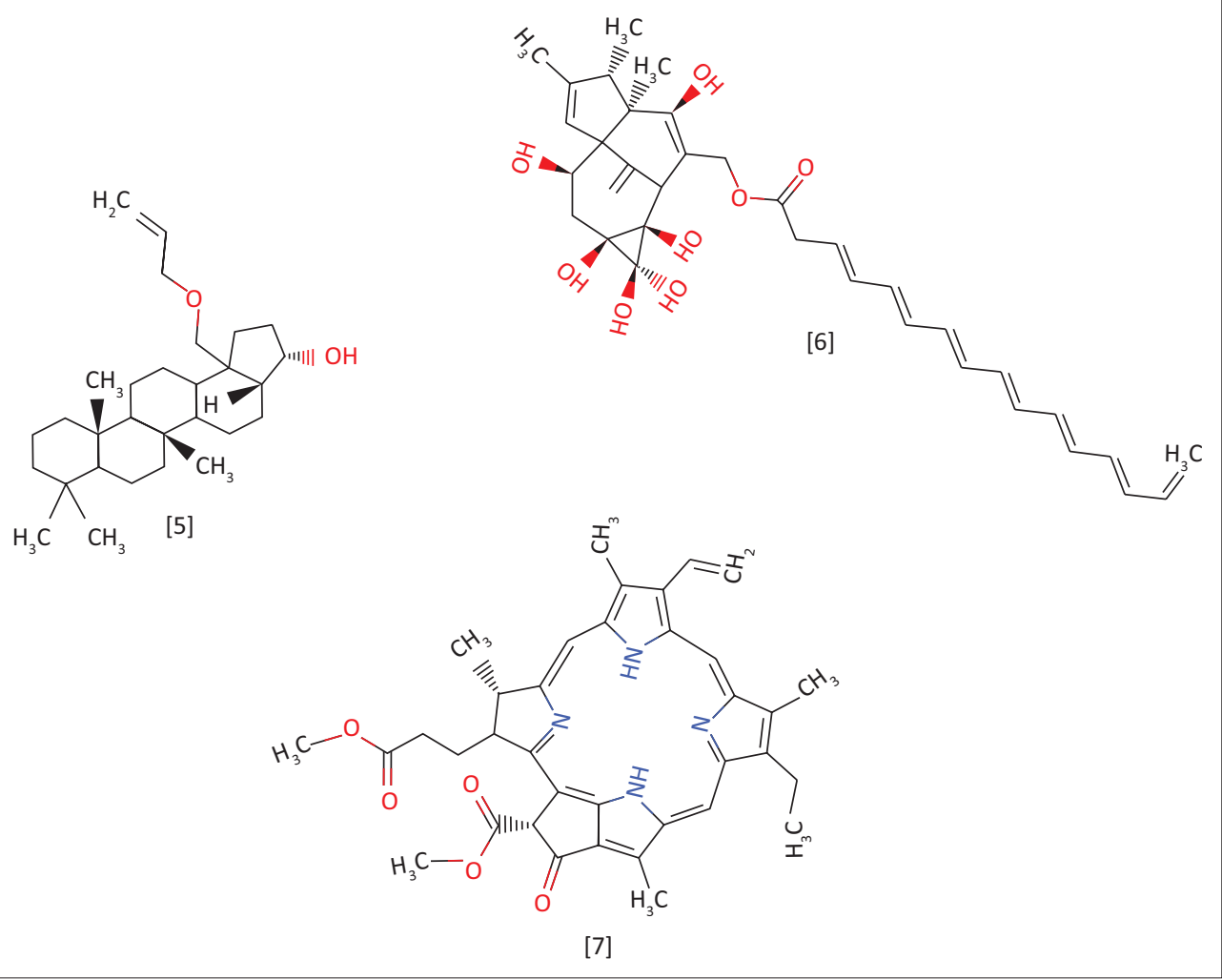

FIGURE 9: Chemical structures of known identified compounds in Alchornea laxiflora.

\section{Discussion}

Alchornea laxiflora has been shown in this study to inhibit spontaneous and OT-induced uterine contraction of the nonpregnant uterus. The uterus is chiefly made up of smooth muscle cells and is characterised by spontaneous and rhythmic oscillations of contractions and relaxations (Kelly 1962; Pehlivanoğlu, Bayrak \& Doğan 2013). This uterine activity of myogenic origin is observed even in denervated preparations (Bulletti et al. 1993). In the non-pregnant uterus, contractions act to expel menstrual debris in the early follicular phase, in propelling spermatozoa from the cervix to the distal tube ends (de Vries et al. 1990), and assist in the return of oocytes or embryos to the uterine cavity. Uterine contractility also favours proper placement of concepti in the uterine cavity and is therefore important in implantation (Bulletti et al. 2000). Abnormal uterine contractility (dyskinesia) may result in pelvic pain (dysmenorrhea), abortion and PTL (Bulletti et al. 1993; Kelly 1962). It has been shown that an increase in frequency of uterine contractions occurs during the follicular phase followed by a decrease during the luteal phase of the menstrual cycle (Bulletti et al. 1993; Lyons et al. 1991). However, the amplitude of uterine contractions increases during the luteal phase and is subsequently decreased at the time of menstruation (Bulletti et al. 2000). The stage of cycle used in this study was the late follicular and ovulation stages where frequency of uterine contractions is high. We observed an initial increase in tension that was attenuated with higher concentrations of the extract resulting in a decrease in amplitude and frequency even in conditions where frequency of contractions is expectedly higher than other cycle phases. Spontaneous contractions have been attributed primarily to the influx of $\mathrm{Ca}^{2+}$ (Shmigol, Eisner \& Wray 1998; Wray et al. 2003) from the intracellular and extracellular spaces (Floyd \& Wray 2007). This therefore suggests a possible inhibition of calcium influx by AL. Stimulation of OT receptor by OT activates the phospholipase $\mathrm{C}$ system, which, in turn, leads to the eventual mobilisation of $\mathrm{Ca}^{2+}$ from intracellular stores; this is considered the canonical pathway for OT stimulation of uterine contractility (Arrowsmith \& Wray 2014; Wray 2007). However, $\mathrm{Ca}^{2+}$ from extracellular space also contributes to the rise in $\left[\mathrm{Ca}^{2+}\right]_{\mathrm{i}}$ stimulated by OT. Contribution of $\mathrm{Ca}^{2+}$ from extracellular space appears to occur via voltageoperated calcium channels (VOCCs) which are also essential for the phasic, spontaneous uterine contractions (Wray et al. 2001). The inhibition of OT by AL additionally supports AL inhibition of $\mathrm{Ca}^{2+}$ but also proposes interaction of AL with the second messenger metabolites involved in OT's activity. That AL inhibits spontaneous and OT-induced uterine 
contractions similarly suggests inhibition of a common signalling pathway that appears to be $\mathrm{Ca}^{2+}$ and more likely inhibition of $\mathrm{Ca}^{2+}$ through VOCCs, as the operation of VOCCs is shared in both spontaneous and OT-induced uterine contractions. In order to investigate this possibility further, the effect of AL on depolarised tissues was studied. This was achieved in the presence of high $\mathrm{KCl}$ which opens L-type VOCCs (Granger, Hollingsworth \& Weston 1986; Niedergerke 1956), resulting in a sustained depolarisation of the tissues (Little, Teaf \& Hurwitz 1985). Again, the depolarisation by $\mathrm{KCl}$ was inhibited by $\mathrm{AL}$ in this study, further supporting the interaction of $\mathrm{AL}$ with $\mathrm{Ca}^{2+}$. Importantly, $\mathrm{Ca}^{2+}$ contribution in uterine contractility involves the intracellular stores as well as the VOCCs. In order to examine the possibility of $\mathrm{AL}$ inhibiting the intracellular release of $\mathrm{Ca}^{2+}$, the activity of AL was examined in $\mathrm{Ca}^{2+}$-free medium. In the absence of $\mathrm{Ca}^{2+}$ in the medium, AL inhibited the effect of OT where $\mathrm{Ca}^{2+}$ arises principally from intracellular stores (Kupittayanant, Luckas \& Wray 2002; Luckas, Taggart \& Wray 1999). This suggests a possible activity of AL on both L-type VOCCs and intracellular $\mathrm{Ca}^{2+}$ stores and also supports interaction with inositol triphosphate $\left(\mathrm{IP}_{3}\right)$, a second messenger involved in OT's contractility by regulating intracellular $\mathrm{Ca}^{2+}$ release (Stepien \& Ziecik 2002; Zingg \& Laporte 2003). In order to investigate possible involvement of $\mathrm{K}^{+}$channels on AL's activity, the extract was tested on OT's effect in the presence of $\mathrm{K}^{+}$channel blockers (AM and GLB). Potassium channels exist in the myometrium and function to neutralise depolarisations and prevent generation of action potentials when necessary (Piedras-Renteria, Stefani \& Toro 1991). Amiodarone and GLB have been reported to inhibit ATP-sensitive $\mathrm{K}^{+}$channels $\left(\mathrm{K}^{+}{ }_{\text {ATP }}\right)$ (Grover \& Garlid 2000; Holmes et al. 2000). Opening of $\mathrm{K}_{\text {ATP }}^{+}$channels in smooth muscle cells would lead to hyperpolarisation of the membranes and eventual relaxation (Grover \& Garlid 2000). Therefore, blockade of $\mathrm{K}^{+}{ }_{\text {ATP }}$ would prevent relaxation and potentiate depolarisation. The effect of AL on OT in the presence of either AM or GLB was more potent than when tested alone, suggesting that in addition to blockade of $\mathrm{Ca}^{2+}$ channels AL also activates opening of $\mathrm{K}^{+}$ channels in the myometrium. Earlier studies had described a progesterone-like effect of AL (Bafor et al. 2016). Progesterone promotes inhibition of the frequency of uterine contractility (Bulletti et al. 2000) and is also necessary for maintaining uterine quiescence during pregnancy (Gellersen, Fernandes $\&$ Brosens 2009). Progesterone is also known to inhibit $\mathrm{Ca}^{2+}$ channels and activate $\mathrm{K}^{+}$-channels (Soloff et al. 2011) and therefore supports the observed effect of AL in this study.

Mass spectrometric analysis led to the identification of seven secondary metabolites and others were unknown. Of those identified some knowledge regarding their biological activity and possible involvement in the activity of AL is described. The metabolite 4-Amino-4-deoxyarabinose is a pentosamine. Pentoses range from complex carbohydrates such as the antibiotic everninomicin to simple sugars such as L-arabinose and L-xylose. Several biological activities of pentose compounds have been reported, ranging from antimicrobial to anticancer activities (Forsman \& Leino 2011). With regard to their involvement with organs of the reproductive system, not much is known; however, sugars have been reported to regulate some ligand function and sperm motility in mice (Chapman \& Barratt 1996). The metabolite 2-methyl-1,2,3,4butanetetrol, also known as 2-methylerythritol, is a soluble carbohydrate that is found in certain higher plants and is likely a dephosphorylated form of 2-C-methyl-D-erythritol-4phosphate (MEP). The form MEP is a central component to the non-mevalonate pathway for isoprenoid synthesis (Witczak, Whistler \& Daniel 1984). As far as contribution to uterine signalling is concerned, no specific relationship has been observed so far. The metabolite 2-amino-4,5-dihydroxy3,4-dimethylpentanoic acid is an amine acid. Amine acids primarily function as components of proteins and some are considered as essential compounds that must be ingested as they partake and support bodily functions including pain relief (Wu 2009). The exact biological role of 2-amino-4,5dihydroxy-3,4-dimethylpentanoic acid in uterine function is, however, unknown at this time. The compound 3-deoxyarabino-hept-2-ulosonic acid is a keto ester (Liu et al. 2002). Keto esters have, however, been reported to inhibit anandamide hydrolase and therefore act as potent fatty acid amide hydrolase (FAAH) inhibitors (Malabu et al. 1992). Fatty acid amide hydrolase is a mammalian integral membrane enzyme that degrades the fatty acid amide family of endogenous signalling lipids, which includes the endogenous cannabinoid anandamide and the sleep-inducing substance oleamide (McKinney \& Cravatt 2005). It has been reported that the uterus is a target for cannabinoid ligand-receptor signalling where it functions maybe to induce myometrial signalling via the adenylate cyclase pathway (Das et al. 1995; Dennedy et al. 2004). This therefore suggests a possible contribution of 3-deoxy-arabino-hept-2-ulosonic acid to the activity of AL in this study. Adipedatol is a triterpenoid (Ageta \& Shiojima 1968). While there is no direct information on the effect of adipedatol on uterine contractility or function, there are studies that report the effect of triterpenoids on uterine contractility. Vaccaroid A, a triterpenoid from seeds of Vaccaria segetalis, has been reported to stimulate uterine contractility (Morita et al. 1997). Quassin, a triterpenoid from stem bark extract of Quassia amara, was also reported to exhibit reversible antifertility and anti-oestrogenic properties (Raji et al. 2010). Dalsaxin, a triterpenoid glycoside isolated from the root of Dalbergia saxatilis, also stimulated uterine contractility in rats (Uchendu \& Leek 1999a, 1999b). It therefore seems that triterpenoids stimulate uterine contractility and adipedatol would not have contributed to the inhibitory effect of AL but may have a role to play in the mild uterine stimulation observed at lower concentrations on spontaneous contractions. The compound 17-hydroxyingenol is a terpene alcohol (Devappa, Makkar \& Becker 2011). Terpene alcohols are commonly used as fragrance and flavour ingredients (Belsito et al. 2008); however, they are known to exert some biological activities as well. For instance, spathulenol, a terpene alcohol from Lepechinia caulescens, was reported to potently inhibit uterine contractility possibly via blockade of VOCCs (PerezHernandez et al. 2008). In addition, 17-hydroxyingenol is known to inhibit phorbol 12,13-dibutyrate (PDBu) binding to protein kinase C (PKC) (Mbwambo et al. 1996). 
Hydroxyingenol actively binds and activates PKC (BlancoMolina et al. 2001). Protein kinase $C$ belongs to the family of serine or threonine kinases and is known to participate in the regulation of uterine smooth muscle contraction and acts primarily to stimulate uterine contractility (Di Liberto et al. 2003; Kim et al. 2006; Phillippe 1994). Inhibition of PKC by hydroxyingenol may therefore also contribute to the effect of AL in this study. Phaeophorbide-a methyl ester, also detected in AL, has been shown to inhibit spontaneous and OT-induced uterine contractility (Bafor et al. 2013) and may therefore contribute to the effect of AL in this study.

\section{Conclusion}

The leaves of A. laxiflora have been shown in this study to exert inhibitory effects on uterine contractility. Its activity appears to occur via blockade of extracellular and intracellular calcium channels and may also involve regulation of $\mathrm{K}^{+}$ channels. The activity of $A$. laxiflora on uterine contractility has also been suggested to be a contribution of 3-deoxyarabino-hept-2-ulosonic acid, 17-hydroxyingenol or phaeophorbide-a methyl ester. These compounds may have acted individually or synergistically to effect the inhibitory activity observed. Further studies on identification of the metabolite directly related to the uterine inhibitory activity of A. laxiflora are therefore suggested. This study has provided data that the leaves of $A$. laxiflora may present as suitable candidates for drug development in the search for useful alternatives for PTL and dysmenorrhoea.

\section{Acknowledgements}

The authors would like to thank Miss I. Okosun for her assistance during the experiments.

\section{Competing interests}

The authors declare that they have no financial or personal relationships which may have inappropriately influenced them in writing this article.

\section{Authors' contributions}

E.E.B. conceptualised and designed the study, participated in the experiments, analysed the data and wrote the manuscript. J.K.N. participated in the experiments and data analysis and was involved in the plant collection, preparation and extraction. J.O, F.A. and B.A. were primarily involved in the plant extraction and manuscript writing. U.B.E. and O.O. participated in the uterine contractility experiments. C.V. and R.E. were involved in the mass spectrometric experiments, interpretation of data and contributed in writing the manuscript.

\section{References}

Ageta, H. \& Shiojima, K., 1968, 'Comparison of adipedatol with hydroxyhopane and hydroxyisohopane', Chemical Communications 22, 1372. https://doi.org/10.1039/ c19680001372

Arrowsmith, S. \& Wray, S., 2014, 'Oxytocin: Its mechanism of action and receptor signalling in the myometrium', Journal of Neuroendocrinology 26(6), 356-369. https://doi.org/10.1111/jne.12154
Ayan, M., Sogut, E., Tas, U., Erdemir, F., Sahin, M., Kaya, Z. et al., 2012, 'Pain levels associated with renal colic and primary dysmenorrhea: A prospective controlled study with objective and subjective outcomes', Archives of Gynecology and Obstetrics 286(2), 403-409. https://doi.org/10.1007/s00404-012-2316-4

Bafor, E.E., Ebidame, V.O., Elvis-Offiah, U.B., Omoruyi, O., Eze, G.I., Igbinuwen, O. et al., 2017, 'A role of alpha-tocopherol and phylloquinone in the modulation of uterine contractility and reproductive function in mouse models', Medicina (B Aires) 53(3), 190-202. https://doi.org/10.1016/j.medici.2017.05.002

Bafor, E.E., Elvis-Offiah, U.B., Omoruyi, O., Onaghino, P., Viegelmann, C. \& EdradaEbel, R., 2016, 'Modulation of uterine contractility in the isolated mouse uterus by the methanol extract of Talinum Triangulare (Portulaceae) and investigation of significant secondary metabolites', African Journal of Pharmaceutical Resarch and Development 8(2), 122-134.

Bafor, E.E., Eyohan, S.E., Omoruyi, O., Elvis-Offiah, U.B., Ayinde, B,A., Eze, G.I. et al., 2016, 'Preliminary endocrinological, histological and haematological investigation of Alchornea laxiflora (Euphorbiaceae) leaf extract effects on the ovary, uterus and cervix of mouse models', Journal of Science and Practice of Pharmacy 2(1), and cervix

Bafor, E.E., Lim, C.V., Rowan, E.G. \& Edrada-Ebel, R., 2013, 'The leaves of Ficus exasperata Vahl (Moraceae) generates uterine active chemical constituents', Journal of Ethnopharmacology 145(3), 803-812. https://doi.org/10.1016/j. jep.2012.12.020

Bafor, E.E., Obarisiagbon, P.A. \& Itamaomon, J.L., 2015, 'Investigation of the myometrial stimulatory effect of amide anaesthetics', Journal of Pharmaceutical and Allied Science 12(1), 2191-2209.

Belsito, D., Bickers, D., Bruze, M., Calow, P., Greim, H., Hanifin, J.F. et al., 2008, 'A toxicologic and dermatologic assessment of cyclic and non-cyclic terpene alcohols when used as fragrance ingredients', Food and Chemical Toxicology 46, S1-S71. https://doi.org/10.1016/j.fct.2008.06.085

Berkman, N.D., Thorp, J.M., Lohr, K.N., Carey, T.S., Hartmann, K.E., Gavin, N.I. et al., 2003, 'Tocolytic, treatment for the management of preterm labor: A review of the evidence', American Journal of Obstetrics and Gynecology 188, 1648-1659. https://doi.org/10.1067/mob.2003.356

Blanco-Molina, M., Tron, G.C., Macho, A., Lucena, C., Calzado, M.A. \& Muñoz, E., 2001 'Ingenol esters induce apoptosis in Jurkat cells through an AP-1 and NF-Kappa B independent pathway', Chemical and Biology 8(8),767-778.

Bocking, A.D., 1998, 'Preterm labour: Recent advances in understanding of pathophysiology, diagnosis and management', Current Opinion in Obstetrics Gynecology 10(2), 151-156. https://doi.org/10.1097/00001703-19980400000012

Bulletti, C., De Ziegler, D., Polli, V., Diotallevi, L., Del Ferro, E. \& Flamigni, C., 2000 'Uterine contractility during the menstrual cycle', Human Reproduction 15, 81-89. https://doi.org/10.1093/humrep/15.suppl_1.81

Bulletti, C., Prefetto, R.A., Bazzocchi, G., Romero, R., Mimmi, P., Polli, V. et al., 1993 'Physiology: Electromechanical activities of human uteri during extra-corporeal perfusion with ovarian steroids', Human Reproduction 8(10):1558-1563. https:// doi.org/10.1093/oxfordjournals.humrep.a137891

Burkill, H.M., 1994, The useful plants of west tropical Africa. Volume 2: Families E-I, 2nd edn., Royal Botanical Gardens, Kew, Richmond, UK.

Caligioni, C.S., 2009, 'Assessing reproductive status/stages in mice', Current Protocols in Neuroscience Appendix 4, Appendix 4l. https://doi.org/10.1002/0471142301. nsa04is48

Campbell, M.A. \& McGrath, P.J., 1997, 'Use of medication by adolescents for the management of menstrual discomfort', Archives of Pediatrics and Adolescent Medicine 151(9), 905-913. https://doi.org/10.1001/archpedi.1997.02170460043 Medicin

Chapman, N.R. \& Barratt, C.L., 1996, 'The role of carbohydrate in sperm-ZP3 adhesion', Molecular Human Reproduction 2(10), 767-774. https://doi.org/10.1093/ molehr/2.10.767

Chen, C.-H., Lin, Y.-H., Heitkemper, M.M. \& Wu, K.-M., 2006, 'The self-care strategies of girls with primary dysmenorrhea: A focus group study in Taiwan', Health Care for Women International 27(5), 418-427. https://doi.org/10.1080/07399330 600629583

Coco, A.S., 1999, 'Primary dysmenorrhea', American Family Physician 60(2), 489-496.

Cora, M.C., Kooistra, L. \& Travlos, G., 2015, 'Vaginal cytology of the laboratory rat and mouse: Review and criteria for the staging of the estrous cycle using stained vaginal smears', Toxicologic Pathology 43(6), 776-793. https://doi.org/10.1177/ 0192623315570339

Creatsas, G., Deligeoroglou, E., Zachari, A., Loutradis, D., Papadimitriou, T., Miras, K. et al., 1990, 'Prostaglandins: PGF2 $\alpha$, PGE2, 6-keto-PGF1 $\alpha$ and TXB2 serum levels in dysmenorrheic adolescents before, during and after treatment with ora contraceptives', European Journal of Obstetrics and Gynecology and Reproductive Biology 36(3), 292-298. https://doi.org/10.1016/0028-2243(90)90213-K

Crichton, C.A., Taggart, M.J., Wray, S. \& Smith, G.L., 1993, 'Effects of pH and inorganic phosphate on force production in alpha-toxin-permeabilized isolated rat uterine smooth muscle', The Journal of Physiology 465, 629-645. https://doi.org/10.1113/ jphysiol.1993.sp019697

Das, S.K., Paria, B.C., Chakraborty, I. \& Dey, S.K., 1995, 'Cannabinoid ligand-receptor signaling in the mouse uterus', Proceedings of the National Academy of Sciences of the United States of America 92(10), 4332-4336. https://doi.org/10.1073/ pnas.92.10.4332

Dawood, M.Y., 1988, 'Nonsteroidal anti-inflammatory drugs and changing attitudes toward dysmenorrhea', American Journal of Medicine 84(5), 23-29. https://doi. org/10.1016/0002-9343(88)90473-1

Dawood, M.Y., 1995, 'Dysmenorrhea', Endometrium 6, 363-377. 
Dennedy, M.C., Friel, A.M., Houlihan, D.D., Broderick, V.M., Smith, T. \& Morrison, J.J., 2004 'Cannabinoids and the human uterus during pregnancy', American Journal of Obstetrics and Gynecology 190, 2-9. https://doi.org/10.1016/j.ajog. of Obstetrics

Devappa, R.K., Makkar, H.P.S. \& Becker, K., 2011, 'Jatropha diterpenes: A review' Journal of the American Oil Chemists' Society 88(3), 301-322. https://doi. org/10.1007/s11746-010-1720-9

de Vries, K., Lyons, E.A., Ballard, G., Levi, C.S. \& Lindsay, D.J., 1990, 'Contractions of the inner third of the myometrium', American Journal of Obstetrics and Gynecology 162(3), 679-682. https://doi.org/10.1016/0002-9378(90)90983-E

Di Liberto, G., Dallot, E., Eude-Le Parco, I., Cabrol, D., Ferre, F. \& Breuiller-Fouche, M. 2003, 'A critical role for PKC zeta in endothelin-1-induced uterine contractions a the end of pregnancy', American Journal of Physiology. Cell Physiology 285(3), C599-C607. https://doi.org/10.1152/ajpcell.00040.2003

Eryilmaz, G., Ozdemir, F. \& Pasinlioglu, T., 2010, 'Dysmenorrhea prevalence among adolescents in Eastern Turkey: Its effects on school performance and relationships with family and friends', Journal of Pediatric and Adolescent Gynecology 23(5), 267-272. https://doi.org/10.1016/j.jpag.2010.02.009

Farombi, E.O., Ogundipe, O.O., Uhunwangho, E.S., Adeyanju, M.A. \& Moody, J.O. 2003, 'Antioxidant properties of extracts from Alchornea laxiflora (Benth) Pax and Hoffman', Phytherapy Research 17, 713-716. https://doi.org/10.1002/ ptr.1050

Floyd, R. \& Wray, S., 2007, 'Calcium transporters and signalling in smooth muscles', Cell Calcium 42(4-5), 467-476. https://doi.org/10.1016/j.ceca.2007.05.011

Forsman, J.J. \& Leino, R., 2011, 'L-Pentoses in biological and medicianl applications', Chemical Reviews 111(5), 3334-3357. https://doi.org/10.1021/cr1002563

Gellersen, B., Fernandes, M.S. \& Brosens, J.J., 2009, 'Non-genomic progesterone actions in female reproduction', Human Reproduction Update 15(1), 119-138. https://doi.org/10.1093/humupd/dmn044

Goldenberg, R.L., 2002, 'The management of preterm labor', Obstetrics and Gynecology 100, 1020-1037.

Goldenberg, R.L., Culhane, J.F., lams, J.D. \& Romero, R., 2008, 'Epidemiology and causes of preterm birth', The Lancet 371, 75-84. https://doi.org/10.1016/S01406736(08)60074-4

Granger, S.E., Hollingsworth, M. \& Weston, A.H., 1986, 'Effects of calcium entry blockers on tension development and calcium influx in rat uterus', British Journal of Pharmacology 87(1), 147-156. https://doi.org/10.1111/j.1476-5381.1986. tb10166.x

Grover, G.J. \& Garlid, K.D., 2000, 'ATP-sensitive potassium channels: A review of their cardioprotective pharmacology', Journal of Molecular and Cellular Cardiology 32(4), 677-695. https://doi.org/10.1006/jmcc.2000.1111

Gruber, C.W. \& O'Brien, M., 2011, 'Uterotonic plants and their bioactive constituents' Planta Medica 77(3), 207-220. https://doi.org/10.1055/s-0030-1250317

Hendrix, S.L. \& Alexander, N.J., 2002, 'Primary dysmenorrhea treatment with a desogestrel-containing low-dose oral contraceptive', Contraception 66(6), 393 399. https://doi.org/10.1016/S0010-7824(02)00414-6

Holmes, D.S., Sun, Z.Q., Porter, L.M., Bernstein, N.E., Chinitz, L.A., Artman, M. et al. 2000, 'Amiodarone inhibits cardiac ATP-sensitive potassium channels', Journal of Cardiovascular Electrophysiolology 11(10), 1152-1158. https://doi.org/10.1111/j. 1540-8167.2000.tb01762.x

Jayeoba, O.J., Ijeomah, H.M. \& Ogara, I.M., 2012, 'Ethnomedical utilization of Alchornea laxiflora (benth) Pax \& K Hoffm in Irepodun/Ifelodun local government area of Ekiti state, southwest, Nigeria', Journal of Agriculture and Social Research 12(2), 85-90.

Keirse, M.J.N.C., 2003, 'The history of tocolysis', BJOG: An International Journal of Obstetrics and Gynaecology 110(Suppl 20), 94-97. https://doi.org/10.1046/j. 1471-0528.2003.00051.x

Kelly, J.V., 1962, 'Myometrial participation in human sperm transport: A dilemma' Fertility and Sterility 13, 84-92. https://doi.org/10.1016/S0015-0282(16)34387-4

Kessner, D., Chambers, M., Burke, R., Agus, D. \& Mallick, P., 2008, 'ProteoWizard Open source software for rapid proteomics tools development', Bioinformatics 24(21), 2534-2536. https://doi.org/10.1093/bioinformatics/btn323

Kim, B., Kim, Y.-S., Ahn, J., Kim, J., Cho, S., Won, K.-J. et al., 2003, 'Conventional-type protein kinase $\mathrm{C}$ contributes to phorbol ester-induced inhibition of rat myometrial tension', British Journal of Pharmacology 139(2), 408-414. https://doi.org/ 10.1038/sj.bjp.0705237

Kinghorn, A.D., Pan, L., Fletcher, J.N. \& Chai, H., 2011, 'The relevance of higher plants in lead compound discovery programs', Journal of Natural Products 74, 15391555. https://doi.org/10.1021/np200391c

Kupittayanant, S., Luckas, M.J.M. \& Wray, S., 2002, 'Effect of inhibiting the sarcoplasmic reticulum on spontaneous and oxytocin-induced contractions of human myometrium', BJOG: An International Journal of Obstetrics and Gynaecology 109, 289-296. https://doi.org/10.1111/j.1471-0528.2002.01110.x

Little, S.A., Teaf, E. \& Hurwitz, L., 1985, 'Cobalt-sensitive biphasic uptake of calcium ions in potassium-depolarized smooth muscle', Journal of Pharmacology and Experimental Therapeutics 232(3), 746-753.

Liu, K.-G., Hu, S.-G., Wu, Y., Yao, Z.-J. \& Wu, Y.-L., 2002, 'A straightforward synthesis of DAH (3-deoxy-D-arabino-hept-2-ulosonic acid) and DRH (3-deoxy-D-ribo-hept-2 ulosonic acid)', Journal of the Chemical Society, Perkin Transactions 1(16), 18901895. https://doi.org/10.1039/b205047a

Liu, P., Duan, J.A., Hua, Y.Q., Tang, Y.P., Yao, X. \& Su, S.L., 2011, 'Effects of Xiang-Fu-SiWu decoction and its main components for dysmenorrhea on uterus contraction', Journal of Ethnopharmacology 133(2), 591-597. https://doi.org/10.1016/j. jep.2010.10.042
Luckas, M.J., Taggart, M.J. \& Wray, S., 1999, 'Intracellular calcium stores and agonistinduced contractions in isolated human myometrium', American Journal of Obstetrics and Gynecology 181(2), 468-476. https://doi.org/10.1016/500029378(99)70580-6

Luzi, L. \& Pozza, G., 1997, 'Glibenclamide: An old drug with a novel mechanism of action?', Acta Diabetologica 34(4), 239-244. https://doi.org/10.1007/ s005920050081

Lyons, E.A., Taylor, P.J., Zheng, X.H., Ballard, G., Levi, C.S. \& Kredentser, J.V., 1991 'Characterization of subendometrial myometrial contractions throughout the menstrual cycle in normal fertile women', Fertility and Sterility 55, 771-774. https://doi.org/10.1016/S0015-0282(16)54246-0

Macintyre, L., Zhang, T., Viegelmann, C., Martinez, I.J., Cheng, C., Dowdells, C. et al., 2014, 'Metabolomic tools for secondary metabolite discovery from marine microbial symbionts', Marine Drugs 12(6), 3416-3448. https://doi.org/10.3390/ microbial sym

Malabu, U.H., McCarthy, H.D., McKibbin, P.E. \& Williams, G., 1992, 'Peripheral insulin administration attenuates the increase in neuropeptide $Y$ concentrations in the hypothalamic arcuate nucleus of fasted rats', Peptides 13(6), 1097-1102. https:// hypothalamic arcuate nucleus of fasted ras',
doi.org/10.1016/0196-9781(92)90013-S

Maltaris, T., Dragonas, C., Hoffmann, I., Mueller, A., Schild, R.L., Schmidt, W. et al., 2006, 'The extracorporeal perfusion of the swine uterus as an experimental model: The effect of tocolytic drugs', European Journal of Obstetrics and model: The effect of tocolytic drugs', European Journal of Obstetrics and
Gynecology and Reproductive Biology 126(1), 56-62. https://doi.org/10.1016/j. Gynecology and Reproc

Marjoribanks, J., Proctor, M., Farquhar, C., Derks, R.S., 2010, 'Nonsteroidal antiinflammatory drugs for dysmenorrhoea', Cochrane Database of Systematic inflammatory drugs for dysmenorrhoea', Cochrane Database of System
Reviews (1), CD001751. https://doi.org/10.1002/14651858.CD001751.pub2

Mbwambo, Z.H., Lee, S.K., Mshiu, E.N., Pezzuto, J.M. \& Kinghorn, A.D., 1996 'Constituents from the stem wood of Euphorbia quinquecostata with phorbol dibutyrate receptor-binding inhibitory activity', Journal of Natural Products 59(11), 1051-1055. https://doi.org/10.1021/np960412e

McKinney, M.K. \& Cravatt, B.F., 2005, 'Structure and function of fatty acid amide hydrolase', Annual Review of Biochemistry 74(1), 411-432. https://doi. org/10.1146/annurev.biochem.74.082803.133450

Mirabi, P., Alamolhoda, S.H., Esmaeilzadeh, S. \& Mojab, F., 2014, 'Effect of medicinal herbs on primary dysmenorrhoea-a systematic review', Iranian Journal of Pharmceutical Research 13(3), 757-767.

Morita, H., Yun, Y.S., Takeya, K., Itokawa, H., Yamada, K. \& Shirota, O., 1997, 'Vaccaroid A, a new triterpenoid saponin with contractility of rat uterine from Vaccaria segetalis', Bioorganic and Medicinal Chemistry Letters 7(8), 1095-1096. https:// doi.org/10.1016/S0960-894X(97)00168-6

National Research Council, 2010, Guide for the care and use of laboratory animals, 8th edn., National Academies Press Washington, DC, USA, p. 118.

Newman, D.J. \& Cragg, G.M., 2012, 'Natural products as sources of new drugs over the 30 years from 1981 to 2010', Journal of Natural Products 75(3), 311-335. https:// doi.org/10.1021/np200906s

Niedergerke, R., 1956, 'The potassium chloride contracture of the heart and its modification by calcium', The Journal of Physiology 134, 584-599. https://doi. org/10.1113/jphysiol.1956.sp005667

$\mathrm{NIH}, 2015$, Public health service policy on humane care and use of laboratory animals, Office of Laboratory Animal Welfare, viewed 20 November 2015, from http:// grants.nih.gov/grants/olaw/references/PHSPolicyLabAnimals.pdf

Ogunfowokan, A.A. \& Babatunde, O.A., 2010, 'Management of primary dysmenorrhea by school adolescents in ILE-IFE, Nigeria', The Journal of School Nursing 26(2), 131-136. https://doi.org/10.1177/1059840509349723

Oloyede, G.K., Onocha, P.A., Adaramoye, O.A. \& Thonda, S.E., 2011, 'Hepatoprotective activity and flavonoids of Alchornea laxiflora leaf extract', Research Journal of Phytochemistry 5, 190-200. https://doi.org/10.3923/rjphyto.2011.190.200

Oloyede, G.K., Onocha, P.A., Soyinka, J., Oguntokun, O. \& Thonda, E., 2010, 'Phytochemical screening, antimicrobial and antioxidant activities of four Nigerian medicinal plants', Annals of Biological Research 1(2), 114-120.

Ortiz, M.I., 2010, 'Primary dysmenorrhea among Mexican university students: Prevalence, impact and treatment', European Journal of Obstetrics and Gynecology and Reproductive Biology 152(1), 73-77. https://doi.org/10.1016/j. ejogrb.2010.04.015

Ou, M.C., Hsu, T.F., Lai, A.C., Lin, Y.T. \& Lin, C.C., 2012, 'Pain relief assessment by aromatic essential oil massage on outpatients with primary dysmenorrhea: A randomized, double-blind clinical trial', Journal of Obstetrics and Gynaecology Research 38(5), 817-822. https://doi.org/10.1111/j.1447-0756.2011.01802.x

Park, K.-S., Park, K.-I., Hwang, D.-S., Lee, J.-M., Jang, J.-B. \& Lee, C.-H., 2014, 'A review of in vitro and in vivo studies on the efficacy of herbal medicines for primary dysmenorrhea', Evidence-Based Complementary and Alternative Medicine 2014 $1-11$.

Pehlivanoğlu, B., Bayrak, S. \& Doğan, M., 2013, 'A close look at the contraction and relaxation of the myometrium; the role of calcium', Journal of the TurkishGerman Gynecological Association 14(4), 230-234. https://doi.org/10.5152/ jtgga.2013.67763

Perez-Hernandez, N., Ponce-Monter, H., Medina, J.A. \& Joseph-Nathan, P., 2008 'Spasmolytic effect of constituents from Lepechinia caulescens on rat uterus', Journal of Ethnopharmacology 115(1), 30-35. https://doi.org/10.1016/j. jep.2007.08.044

Phillippe, M., 1994, 'Protein kinase C, an inhibitor of oxytocin-stimulated phasic myometrial contractions', Biology of Reproduction 50(4), 855-859. https://doi. org/10.1095/biolreprod50.4.855 
Piedras-Renteria, E., Stefani, E. \& Toro, L., 1991, 'Potassium currents in freshly dispersed myometrial cells' American Journal of Physiology-Cell Physiology 261(2), C278-C284. https://doi.org/10.1152/ajpcell.1991.261.2.C278

Pluskal, T., Castillo, S., Villar-Briones, A. \& Oresic, M., 2010, 'MZmine 2: Modular framework for processing, visualizing, and analyzing mass spectrometry-based molecular profile data', BMC Bioinformatics 11, 395. https://doi.org/10.1186/ 1471-2105-11-395

Proctor, M., Farquhar, C., Stones, W., He, L., Zhu, X. \& Brown, J., 2010, 'Transcutaneous electrical nerve stimulation for primary dysmenorrhoea (Review)', Cochrane Database of Systematic Reviews (1), 1-48, CD002123.

Proctor, M. \& Murphy, P.A., 2001, 'Herbal and dietary therapies for primary and secondary dysmenorrhoea', Cochrane Database of Systematic Reviews (3), CD002124.

Raji, Y., Akinola, A., Oyeyipo, I.P. \& Femi-Akinlosotu, O., 2010, 'Reproductive activities of female albino rats treated with quassin, a bioactive triterpenoid from stem bark extract of Quassia amara', Nigerian Journal of Physiological Sciences 25(2), 95-102.

Shmigol, A.V., Eisner, D.A. \& Wray, S., 1998, 'Properties of voltage-activated [ $\left.\mathrm{Ca}^{2+}\right]$ (i) transients in single smooth muscle cells isolated from pregnant rat uterus', Th Journal of Physiology 511(3), 803-811. https://doi.org/10.1111/j.1469-7793. 1998.803bg.X

Soloff, M.S., Jeng, Y.-J., Izban, M.G., Sinha, M., Luxon, B.A., Stamnes, S.J. et al., 2011 'Effects of progesterone treatment on expression of genes involved in uterine quiescence', Reproductive Sciences 18(8), 781-797. https://doi.org/ 10.1177/1933719111398150

Steer, P. \& Flint, C., 1999, 'Preterm labour and premature rupture of membranes', British Medical Journal 318(7190), 1059-1062. https://doi.org/10.1136/bmj.318.7190.1059

Stepien, A. \& Ziecik, A.J., 2002, 'Second messenger systems in the action of LH and oxytocin on porcine endometrial cells in vitro', Theriogenology 57(9), 2217-2227. https://doi.org/10.1016/S0093-691X(02)00825-7

Sukwan, C., Wray, S. \& Kupittayanant, S., 2014, 'The effects of Ginseng Java root extract on uterine contractility in nonpregnant rats', Physiological Reports 2(12) e12230-e12230. https://doi.org/10.14814/phy2.12230

Taylor, D., Miaskowski, C. \& Kohn, J., 2002, 'A randomized clinical trial of the effectiveness of an acupressure device (relief brief) for managing symptoms of dysmenorrhea', Journal of Alternative and Complementary Medicine 8(3), 357370. https://doi.org/10.1089/10755530260128050

Triggle, D.J., 1987, 'Calcium channel ligands', Annual Review of Pharmacology and Toxicology 27, 347-369. https://doi.org/10.1146/annurev.pa.27.040187.002023

Uchendu, C.N. \& Leek, B.F., 1999a, 'Adrenergic influence of uterine muscle contractions stimulated by a glycoside from the root of Dalbergia saxatilis', Indian Journal of Experimental Biology 37, 350-354.
Uchendu, C.N. \& Leek, B.F., 1999b, 'Uterine muscle contractant from the root of Dalbergia saxatilis', Fitoterapia 70(1), 50-53. https://doi.org/10.1016/S0367326X(98)00019-7

Van Andel, T., De Boer, H.J., Barnes, J. \& Vandebroek, I., 2014, 'Medicinal plants used for menstrual disorders in Latin America, the Caribbean, sub-Saharan Africa, South and Southeast Asia and their uterine properties: A review', Journal of Ethnopharmacology 155(2), 992-1000. https://doi.org/10.1016/j.jep.2014. Ethnop 06.049

Witczak, Z.J., Whistler, R.L. \& Daniel, J.R., 1984, 'Synthesis of 3-C-(hydroxymethyl) erythritol and 3-C-methylerythritol', Carbohydrate Research 133(2), 235-245. https://doi.org/10.1016/0008-6215(84)85201-5

Wong, L.P. \& Khoo, E.M., 2010, 'Dysmenorrhea in a multiethnic population of adolescent Asian girls', International Journal of Gynecology and Obstetrics 108(2) 139-142. https://doi.org/10.1016/j.ijgo.2009.09.018

World Health Organization, 2016, The international pharmacopoeia, 6th edn., Oxytocin, Geneva, Switzerland.

Wray, S., 2007, 'Insights into the uterus', Experimental Physiology 92(4), 621-631. https://doi.org/10.1113/expphysiol.2007.038125

Wray, S. \& Arrowsmith, S., 2012, 'Uterine smooth muscle', Fundam Biology and Mechanisms of Disease 2, 1207-1216. https://doi.org/10.1016/B978-0-12 381510-1.00090-9

Wray, S., Jones, K., Kupittayanant, S., Li, Y., Matthew, A., Monir-Bishty, E. et al., 2003 , 'Calcium signaling and uterine contractility', Journal of the Society for Gynecologic Investigation 10, 252-264, viewed 04 May 2016, from http://www.ncbi.nlm.nih gov/pubmed/12853086

Wray, S., Kupittayanant, S., Shmygol, A., Smith, R.D. \& Burdyga, T., 2001, 'The physiological basis of uterine contractility: A short review', Expermental Physiology 86, 239-246. https://doi.org/10.1113/eph8602114

Wu, G., 2009, 'Amino acids: Metabolism, functions, and nutrition', Amino Acids 37, 1-17. https://doi.org/10.1007/s00726-009-0269-0

Zhang, Y., Colenso, C.K., El Harchi, A., Cheng, H., Witchel, H.J., Dempsey, C.E. et al, 2016, 'Interactions between amiodarone and the hERG potassium channel pore determined with mutagenesis and in silico docking', Biochemical Pharmacolgy 113, 24-35. https://doi.org/10.1016/j.bcp.2016.05.013

Zingg, H.H. \& Laporte, S.A., 2003, 'The oxytocin receptor', Trends in Endocrinology \& Metabolism 14, 222-227. https://doi.org/10.1016/S1043-2760(03)00080-8

Zuliani, V., Patel, M.K., Fantini, M. \& Rivara, M., 2009, 'Recent advances in the medicinal chemistry of sodium channel blockers and their therapeutic potential', Current Topics Medicinal Chemistry 9(4), 396-415. https://doi.org/10.2174/ 156802609788317856 